Review

\title{
Enhancing road verges to aid pollinator conservation: A review
}

\author{
Benjamin B. Phillips $^{\mathrm{a}, *}$, Claire Wallace ${ }^{\mathrm{b}}$, Bethany R. Roberts ${ }^{\mathrm{a}}$, Andrew T. Whitehouse ${ }^{\mathrm{c}}$, \\ Kevin J. Gaston ${ }^{\mathrm{a}}$, James M. Bullock ${ }^{\mathrm{d}}$, Lynn V. Dicks ${ }^{\mathrm{b}, \mathrm{e}}$, Juliet L. Osborne ${ }^{\mathrm{a}}$ \\ ${ }^{a}$ Environment and Sustainability Institute, University of Exeter, Penryn Campus, Penryn, Cornwall TR10 9FE, United Kingdom \\ ${ }^{\mathrm{b}}$ School of Biological Sciences, University of East Anglia, Norwich NR4 7TJ, United Kingdom \\ ${ }^{\mathrm{c}}$ Buglife, The Lindens, 86 Lincoln Road, Peterborough, PE1 2SN, United Kingdom \\ ${ }^{\mathrm{d}}$ UK Centre for Ecology and Hydrology, Maclean Building, Wallingford, Oxfordshire OX10 8BB, United Kingdom \\ ${ }^{\mathrm{e}}$ Department of Zoology, University of Cambridge, Cambridge CB2 3EJ, United Kingdom
}

\section{A R T I C L E I N F O}

\section{Keywords:}

Roadside

Highway

Corridor

Roadkill

Pollution

Mowing

Insects

Bees

Butterflies

Moths

Flies

Beetles

\begin{abstract}
A B S T R A C T
Road verges provide habitats that have considerable potential as a tool for pollinator conservation, especially given the significant area of land that they collectively cover. Growing societal interest in managing road verges for pollinators suggests an immediate need for evidence-based management guidance.

We used a formal, global literature review to assess evidence for the benefits of road verges for pollinators (as habitats and corridors), the potential negative impacts of roads on pollinators (vehicle-pollinator collisions, pollution, barriers to movement) and how to enhance road verges for pollinators through management.

We identified, reviewed and synthesised 140 relevant studies. Overall, the literature review demonstrated that: (i) road verges are often hotspots of flowers and pollinators (well established), (ii) traffic and road pollution can cause mortality and other negative impacts on pollinators (well established), but available evidence suggests that the benefits of road verges to pollinators far outweigh the costs (established but incomplete), and (iii) road verges can be enhanced for pollinators through strategic management (well established). Future research should address the lack of holistic and large-scale understanding of the net effects of road verges on pollinators.

We provide management recommendations for enhancing both individual road verges for pollinators (e.g. optimised mowing regimes) and entire road networks (e.g. prioritising enhancement of verges with the greatest capacity to benefit pollinators), and highlight three of the most strongly supported recommendations: (i) creating high quality habitats on new and existing road verges, (ii) reducing mowing frequency to $0-2$ cuts/year and (iii) reducing impacts of street lighting.
\end{abstract}

\section{Introduction}

Animal pollinators are essential for the production of many crops (Klein et al., 2007) and for the reproduction of many wild plants (Ollerton et al., 2011), yet declines of some pollinator species have been recorded in several regions worldwide (Potts et al., 2016). A central cause of declines is the loss and degradation of suitable habitats due to urban and agricultural expansion and intensification (Potts et al., 2016). Pollinators require habitats for feeding (e.g. nectar and pollen, larval hostplants), reproduction, nesting and overwintering. Adequate provision of suitable habitats is therefore crucial to pollinator conservation.

Roads are a ubiquitous feature of human civilisation that extend 36 million $\mathrm{km}$ across the world (Central Intelligence Agency, 2017). Whilst they cause a wide range of negative ecological impacts (Forman et al.,
2003; Muñoz et al., 2015), the habitats alongside roads, henceforth "road verges", can support many species (Gardiner et al., 2018). Road verges are vegetated strips, generally consisting of grassland, shrubland, woodland or forest, which often form distinctly managed borders that separate roads from adjacent land. They may serve a number of practical purposes, for example accommodating road infrastructure, improving visibility for road users and providing refuge for pedestrians, but can simultaneously be managed to benefit wildlife (Gardiner et al., 2018). Given the extent of the road network, road verges cover very large areas of land: an estimated $2400 \mathrm{~km}^{2}$ (1\% of land) in Great Britain (Plantlife, 2013), 50,000 $\mathrm{km}^{2}$ (0.5\% of land) in the USA (Forman et al., 2003) and $270,000 \mathrm{~km}^{2}$ globally (Phillips et al., 2020). As such, verges provide a significant opportunity to benefit wildlife, especially pollinators because many such taxa are highly mobile and so able to use small, isolated habitat patches across landscapes.

\footnotetext{
* Corresponding author.

E-mail address: B.B.Phillips@exeter.ac.uk (B.B. Phillips).
} 
In light of concerns about pollinator declines, there is growing societal interest in managing road verges for pollinators. In the UK, a campaign by the charity Plantlife is proposing road verge management guidelines that benefit plants, pollinators and other wildlife (developed in partnership with highways agencies, highways managers and conservation organisations), which have been adopted by regional governments in a number of areas (Plantlife, 2020). Several other UK organisations have projects involving managing road verges for pollinators, including Highways England (Highways England, 2019), Butterfly Conservation (Butterfly Conservation, 2020) and Buglife (Buglife, 2020). There are similar projects in other countries, including in the USA by the Monarch Joint Venture to support the monarch butterfly Danaus plexippus (Monarch Joint Venture, 2020) and by the Xerces Society to support pollinators generally (Xerces Society, 2020).

In light of growing societal interest in managing road verges for pollinators, practitioners have an immediate need for an evidence synthesis to inform guidelines. Whilst existing reviews have considered the use and management of road verges for nature conservation in general (Gardiner et al., 2018; Jakobsson et al., 2018; Villemey et al., 2018), they identify relatively few studies on pollinators and highlight that many of the related issues are taxon specific. Similarly, the recent IPBES pollinator assessment identified the potential of road verges as habitats and corridors for pollinators, but provides only a brief overview, highlights uncertainty about possible negative impacts of traffic and pollution and provides little advice on how to manage them effectively (IPBES, 2019). This review provides a detailed consideration of each of the issues around using road verges for the conservation of pollinators - a specific focal group that is of major scientific and societal interest. Specifically, the benefits that road verges provide to pollinators must be weighed against the potential negative impacts of roads: road verges may provide beneficial habitats for feeding, reproduction, nesting and overwintering that are scarce in the surrounding landscape, and act as corridors or navigational features; but the pollinators drawn to road verges may be negatively affected by pollution, vehicle-pollinator collisions and poor management, possibly resulting in net harm to these species at the landscape scale (i.e. ecological traps; Hale and Swearer, 2016). In most cases, road verges are already present alongside existing roads and will be constructed along new roads regardless, but they could be enhanced to benefit pollinators. In this study, we used a formal, comprehensive literature review of global scope to address the following questions (Fig. 1):

Q1) What pollinator communities and associated resources are found in road verges, and how do they compare to those in other habitats in the surrounding landscape?

Q2) How do roads and road verges affect pollinator movement and dispersal?

Q3) How much do vehicle-pollinator collisions affect pollinators?

Q4) How much does road pollution affect pollinators?

Q5) How does road verge management affect pollinators?

Q6) How do road verge, road and landscape characteristics affect pollinators in road verges?

In each case, we consider impacts on pollinator individuals, populations and communities.

\section{Materials \& methods}

We carried out a search using Web of Science Core Collection databases (in English language only) for scientific publications addressing the outlined research questions (Fig. 1) - relating to both pollinators and road verges, or to impacts of roads on pollinators. Following much of the literature and conservation strategy documents, we use the term 'pollinators' for all flower visitors that are likely to have the potential to transfer pollen. We aimed for a formal, representative and comprehensive review, and so used detailed search criteria, which were refined by testing against a set of fifteen papers known to be relevant (Appendix A). All studies up to 1st November 2019 were considered. The search criteria resulted in 629 studies. Studies were split between two reviewers, who assessed them (using the title and abstract, or full text where necessary) against the inclusion criteria in Appendix A. Relevant studies were recorded in a spreadsheet, allocated to the relevant research question from Fig. 1 and relevant information was extracted. To ensure consistency in studies that were considered to be relevant, the first reviewer verified the relevance of each of the second reviewer's allocated studies. Verification did not result in any excluded studies being included, though several included studies were excluded. Extracted information was used to write a narrative synthesis of the combined results.

We used meta-analysis to assess how the density and species richness of flowers and pollinators in road verges compared to in other habitats (Q1). For each study that compared flower or pollinator density or species richness, we extracted the mean, standard deviation and sample size from the text, tables, graphs (using WebPlotDigitizer 4.2; Rohatgi, 2015), appendices, or raw data provided by the authors. Studies were split into individual cases of a single habitat comparison for a single pollinator taxon, i.e. each study could provide many individual cases. When data were provided for multiple time points (e.g. multiple surveys across the same year, presented separately), we used the comparisons from the middle time point. Where comparisons were provided for multiple taxonomic levels of pollinators, we used the lowest taxonomic level provided (excluding species, which would have resulted in two studies on Lepidoptera providing the majority of cases). When the mean and standard deviation were not provided, we calculated the standard deviation from the standard error or confidence intervals, or estimated the mean and standard deviation from the median and quartiles using the method of Wan et al. (2014). Of 41 studies initially identified, 14 provided sufficient information (details in Appendices A-B). Meta-analyses were conducted in R 3.6.1 (R Core Team, 2019) using the 'metafor' package (Viechtbauer, 2010). We used Hedge's $d$ standardised mean difference as a measure of the effect size and compared the mean effect size for each pollinator taxa and habitat comparison. Studies were weighted by the inverse of the variance. We tested the significance of the main effects using mixed models with restricted maximum-likelihood estimator, with taxa and habitat comparison as moderator effects, and study cases nested within studies as a random effect. It was not possible to use meta-analysis to address the other research questions due to a lack of studies providing similar comparisons or quantitative outcomes.

\section{Results \& discussion}

We identified 140 relevant studies (Appendix A). All but one study had been published since 1990 and $61 \%$ had been published since 2015 , demonstrating that this is a rapidly growing research area. Studies covered a diverse range of road types; of studies that provided information, most included at least 10 road verges and focused on paved roads (including large, busy, high-speed roads, quiet rural roads in agricultural landscapes, urban roads and forest roads - often a mixture of these), though at least 15 studies focused on (or included) unpaved roads (Appendix A). However, studies were limited in terms of (i) geographic location, (ii) pollinator taxa and (iii) methodology. Geographically, most studies were from Europe (72 studies, 51\%) and North America (45 studies, 32\%). Taxonomically, only 11 studies considered entire pollinator communities, whilst 46 studies (33\%) focused on a single species (including 15 studies on monarch butterflies Danaus plexippus and 13 studies on honeybees Apis mellifera) and 49 studies (35\%) focused on a single pollinator order. Overall, 64 studies (52\%) focused on Lepidoptera and 32 studies (26\%) on Hymenoptera, whilst only 6 studies focused on other pollinator taxa such as Diptera or Coleoptera (Appendix A). Methodologically, most studies were purely observational (104 studies, 74\%), whilst 27 studies (19\%) were 


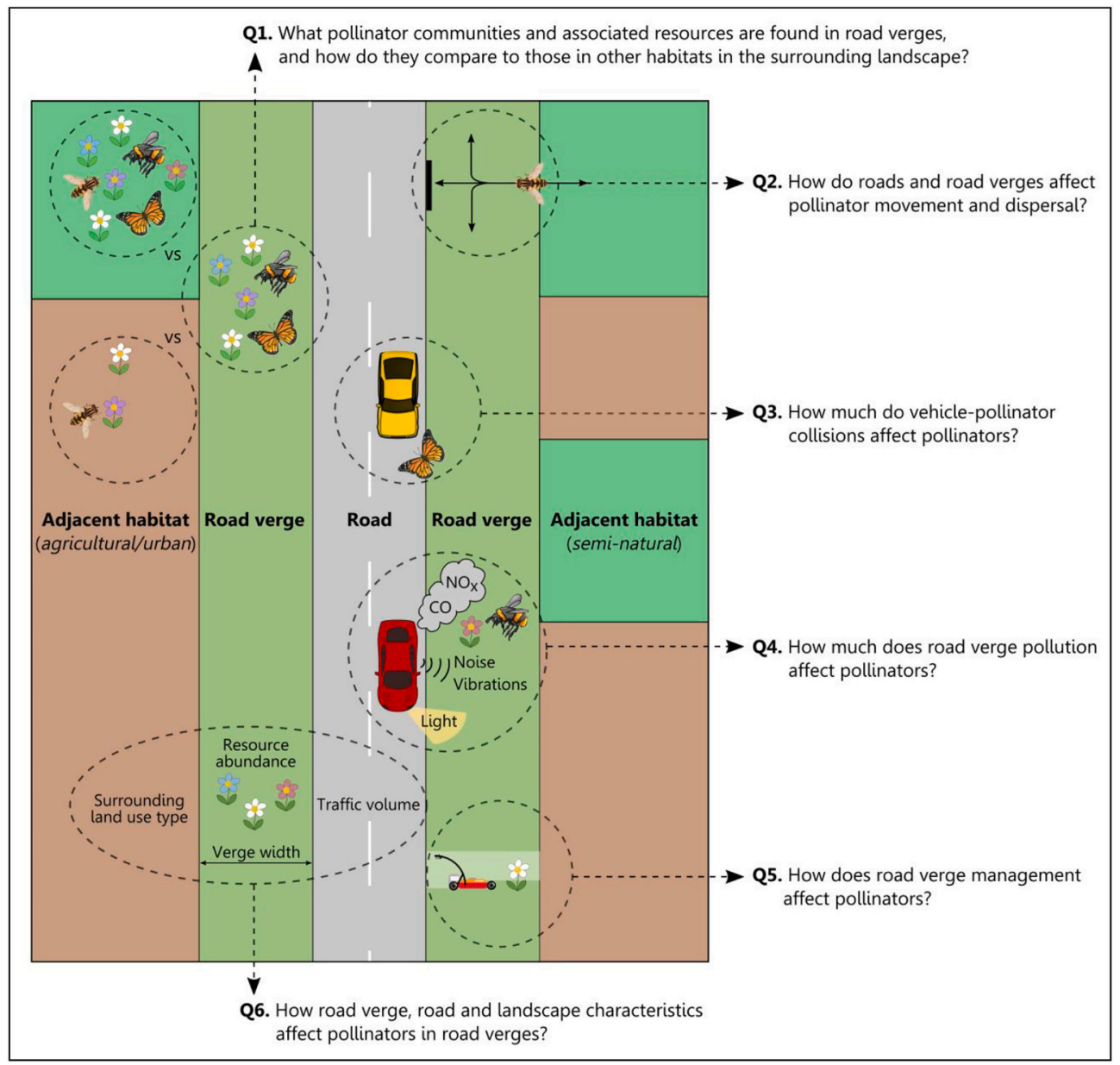

Fig. 1. The research questions about the positive and negative aspects of roads and road verges for pollinators, which are addressed in this review.

experimental, 2 used modelling and 7 were reviews. These limitations mirror those of other systematic reviews (e.g. Villemey et al., 2018), and may introduce bias into the conclusions drawn and limit generalisability because: (i) Road verges might be relatively more important for pollinators in Europe and North America where there is less remaining natural and semi-natural habitat, (ii) The behaviours and responses of hymenopteran and lepidopteran pollinators are not necessarily representative of other pollinator taxa, and (iii) The low number of experimental studies makes it difficult to disentangle drivers of effects of roads, road verges and their management on pollinators. Studies were also apparently dominated by those of grassland road verges, with few considering other common verge habitats (e.g. shrubland) or habitats that are important for pollinator lifecycles but which may be lacking on road verges (e.g. areas of wetland as larval habitats for dipteran pollinators and areas of bare ground as nesting habitats for hymenopteran pollinators). Future studies should focus on other continents, consider entire pollinator communities and nongrassland road verge habitats, and where possible carry out experimental studies. Nevertheless, we found at least 17 relevant studies addressing each research question. We take the research questions in turn. Then we provide an overall assessment, an agenda for future research and management recommendations. Additional information and interpretation of the reviewed studies are provided in Appendix A.

3.1. Q1) What pollinator communities and associated resources are found in road verges, and how do they compare to those in other habitats in the surrounding landscape?

Many studies provide information about the pollinator communities and associated resources that are found in road verges (Appendix A), so we provide a summary and some key examples. Road verges are often important early or mid-successional habitats providing feeding and reproductive opportunities for pollinators including diverse floral resources (e.g. Halbritter et al., 2015; Noordijk et al., 2009; Phillips et al., 2019) and larval hostplants (e.g. Munguira and Thomas, 1992; Valtonen et al., 2006b). Notably, road verges in North America are an important source of milkweeds (Asclepias spp.) - the larval hostplant of monarch butterflies (e.g. Daniels et al., 2018; Kasten et al., 2016). Unsurprisingly then, road verges can contain diverse pollinator communities (Hopwood, 2008; Munguira and Thomas, 1992; Phillips et al., 2019; Valtonen et al., 2006b), including rare species. For example, Heneberg et al. (2017) recorded 32 threatened (including four critically endangered) bee and wasp species from 14 verges along a single highway in the Czech Republic, and Helldin et al. (2015) found that road verges in Sweden contained $>20 \%$ of observations for 13 redlisted pollinator species ( 5 bee, 6 moth and 2 butterfly species) despite only covering $1.5 \%$ of land. Beyond feeding, there is evidence that road verges are used by hymenopteran pollinators for nesting (Heneberg et al., 2017; Hopwood, 2008; Oleksa et al., 2013; Wuellner, 1999), by lepidopteran pollinators for reproduction (e.g. Goodwin et al., 2017; Munguira and Thomas, 1992) and by various pollinator taxa for overwintering (both as adults and as immature stages, further evidencing reproduction in road verges; Schaffers et al., 2012), though these aspects of pollinator lifecycles have been far less studied.

\subsubsection{How do road verges compare to other nearby habitats?}

We found 41 studies comparing pollinators and their associated resources in road verges to other habitats (Appendix A), including 14 
(a) Density of flowers and pollinator taxa

in road verges compared to in other habitats

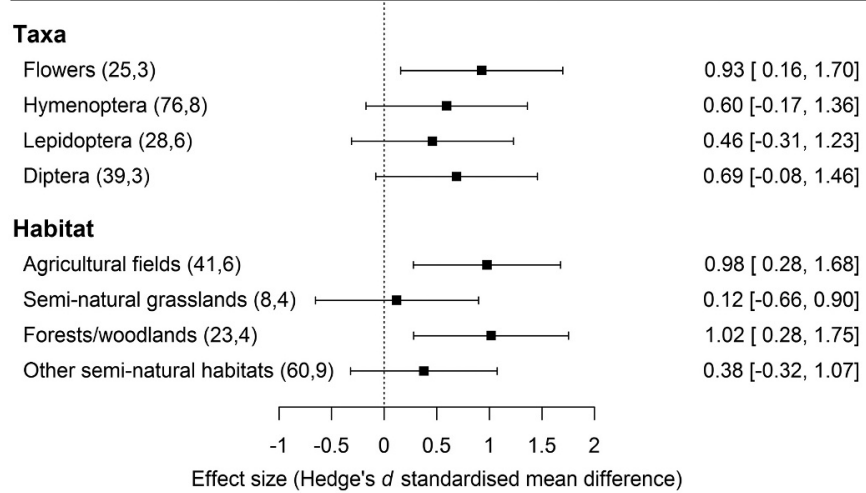

(b) Species richness of flowers and pollinator taxa in road verges compared to in other habitats

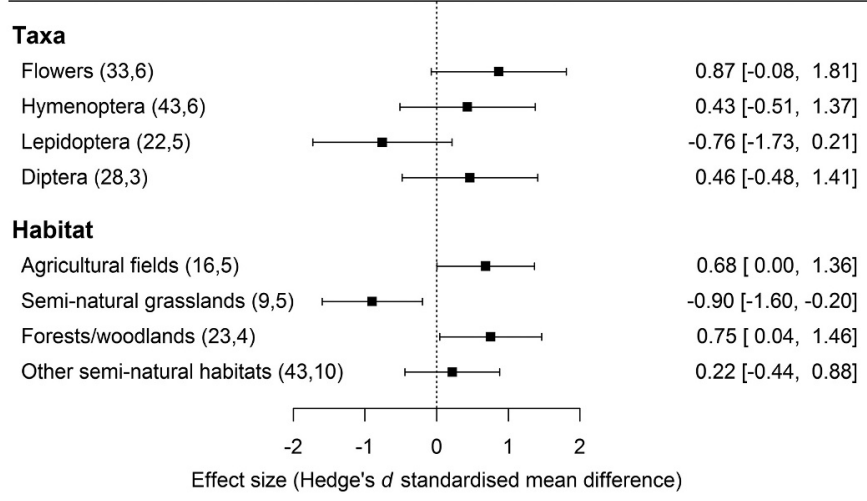

Fig. 2. The mean effect sizes (Hedge's $d$; mean $\pm 95 \%$ confidence intervals) for studies comparing the (a) density and (b) species richness of flowers and pollinators in road verges to those in agricultural fields, semi-natural grasslands, forests/woodlands, and other semi-natural habitats (e.g. hedges). Studies $(n=14)$ were identified from the literature review (Appendix A) and were split into individual cases $(n=300)$ of a single habitat comparison for a single pollinator taxon, i.e. each study could provide many individual cases (cases per study: median $=5$, range $=1-88$ ). Mean effect sizes are only presented for groups where there was more than one study. Numbers in round brackets are the number of study cases and the number of studies for each category. The full list of studies, cases and effect sizes are provided in Appendix B.

studies comparing the density or species richness of flowers or pollinators (Appendix B). Most studies refer to measures of abundance, but in fact measure density, namely counts per total area of a transect survey, so we use the term density throughout for clarity.

Overall, meta-analysis revealed that the density and species richness of flowers and pollinators in road verges are generally similar or greater than in other habitats in the surrounding landscape (Fig. 2). However, patterns differ depending on the habitat comparison: flower and pollinator density and species richness are greater in road verges than in agricultural fields or forests and woodlands, and similar to those in other semi-natural habitats (Fig. 2), but the species richness of flowers and pollinators is lower in road verges than in semi-natural grasslands (Fig. 2b). Studies in UK agricultural landscapes find that pollinator communities in road verges are similar to in other semi-natural habitats and far richer than in agricultural fields (Hanley and Wilkins, 2015; Osgathorpe et al., 2012; Phillips et al., 2019), with the most extensive study finding generally at least 3-4 times greater densities and 1.5 times greater species richness of bumblebees, butterflies and hoverflies than in field interiors and most semi-natural habitats (Cole et al., 2017). Hall et al. (2019) found more mixed results for wild bees in an agricultural landscape in Australia, compared to open farmland and other linear semi-natural habitats. Studies in forested landscapes in Canada and Sweden suggest that road verges provide important open habitats; allowing light infiltration that results in a more favourable microclimate for pollinators and their hostplants (Hanula et al., 2016), resulting in greater density and species richness of butterflies (Berg et al., 2011; Riva et al., 2018) and bumblebees (Hill and Bartomeus, 2016). The role of road verges in providing favourable microclimates and conditions (e.g. south-facing slopes) in non-forested landscapes has been little studied. Furthermore, just a single study has compared flowers and pollinators in urban road verges to other urban habitats: Baldock et al. (2019) found that urban road verges in three UK cities supported similar densities and species richness of flowers, bees, hoverflies and other flies to most other urban habitats and land-use types, though generally much lower than in gardens and allotments. Beyond feeding, only five studies (limited to monarch butterflies) have compared the availability and use of resources for other aspects of pollinator lifecycles in road verges to other habitats. They show that road verges have similar or greater densities of milkweeds (larval hostplants) compared to arable fields and restored prairie, but lower densities than remnant prairie (Hartzler and Buhler, 2000; Kaul and Wilsey, 2019) and an average of roughly $25-50 \%$ fewer monarch eggs and larvae per milkweed plant than in various non-roadsite habitats (Kasten et al., 2016; Pitman et al., 2018). Future research should compare pollinator nesting, reproduction and overwintering in road verges to in other habitats.

\subsection{Q2) How do roads and road verges affect pollinator movement and dispersal?}

Roads might be a partial or complete barrier to movement for pollinators, though might also act as navigational aids, and road verges might act as parallel corridors along which pollinators move and disperse, so improving habitat connectivity at a landscape scale. We found 23 relevant studies, with 15 focusing on butterflies.

\subsubsection{Do pollinators cross roads?}

Roads might present a barrier to pollinator movement if pollinators are not physically able to cross, or if they are deterred from doing so by some aspect of the road. This will largely depend on pollinator flight range and flight height, which are affected by taxon and whether the pollinator is foraging, dispersing or migrating. Roads are unlikely to be a barrier to larger-scale movements by pollinators (e.g. migration), which are generally direct, cover large distances, are at altitudes of up to hundreds of metres, and use environmental cues that are unlikely to be affected by roads (Chapman et al., 2011). For example, bumblebees Bombus spp. can fly distances of several kilometres (Greenleaf et al., 2007), and migrating monarch butterflies readily cross roads, mostly at heights of $>6 \mathrm{~m}$ (Mora Alvarez et al., 2019). However, most studies that we found focus on local-scale movement of pollinators, where pollinators with shorter flight ranges might be physically unable to cross roads, or otherwise where pollinators are more likely to be deterred from crossing roads because they are responding to local cues (e.g. from floral resources or the road).

Evidence from four mark-recapture studies shows that butterflies are able to cross roads, but that sedentary species are less likely to do so than expected by chance. This was found to be the case for three busy main roads (Munguira and Thomas, 1992; Remon et al., 2018) and similarly for a relatively quiet road (approximately 1500 vehicles/day; Polic et al., 2014), though Valtonen and Saarinen (2005) found that a third fewer butterflies crossed a main highway than nearby smaller roads. Similarly, three studies on bees and wasps provide preliminary evidence that roads are a partial barrier to movement, especially for smaller species, which typically have shorter flight ranges (Greenleaf et al., 2007). First, a mark-recapture study in Boston, USA found that bumblebees displaced to a foraging site on the opposite side of a road 
(4-lane, $14 \mathrm{~m}$ wide) soon crossed the road to return to their original site, but rarely crossed the road naturally (without artificial displacement) due to high foraging site fidelity (Bhattacharya et al., 2003). Second, studies of bees and wasps near Stockholm, Sweden found a significantly different community composition between the two sides of a large highway (90,000 vehicles/day) despite similar vegetation, especially for smaller species (Andersson et al., 2017), and that the density and species richness at 23 urban locations were best explained using cost-weighted distance based on landscape friction, with large roads, other paved ground and built-up land acting as barriers (Johansson et al., 2018). Similarly, studies along small, often unpaved rural roads reaffirm that they are a minor barrier to movement for butterflies (Ries et al., 2001; Ries and Debinski, 2001; Severns, 2008), but two studies suggest they can be a major barrier for smaller species. First, a study on the hoverfly Melanostoma fasciatum found that dispersal was equally reduced by different types of bare ground (a road, dirt track or ploughed field) (Lövei et al., 1998). Second, mark-recapture of a rare, specialised solitary bee Andrena hattorfiana found that unpaved roads were a barrier, even when $<10 \mathrm{~m}$ wide (Franzén et al., 2009). Overall, evidence suggests that roads are a relatively minor barrier to local-scale movement for larger and more mobile species such as butterflies and bumblebees, but can be a major barrier for some smaller and less mobile pollinator taxa.

\subsubsection{Are roads and their verges used by pollinators as corridors for movement and dispersal?}

Road verges that provide the habitat requirements for pollinator species may facilitate their movement and dispersal across landscapes. We found six relevant studies, with five on Lepidoptera. Brunzel et al. (2004) found that the probability of colonization by the moth Tyria jacobaea was greater when the site was linked to the nearest population by a road, probably due to provision of their larval hostplant in road verges. Similarly, a study modelling monarch butterfly movement and egg-laying suggested that they preferentially moved along road verges due to high hostplant density (Grant et al., 2018). Gene flow of Maniola jurtina butterflies was positively related to the proportion of road, perhaps because road verges were facilitating dispersal (Villemey et al., 2016). A mark-recapture study of a rare butterfly Phengaris nausithous found lower dispersal rates in road verges than in meadows (Jansen et al., 2012). A study of four butterfly species observed almost twice as many individuals moving along experimental grass strips (simulating road verges) compared to a control ( $22 \%$ versus $12 \%)$, but only the two habitat specialist species moved along the grass strips more than expected by chance, and only when the strips provided food or shelter (Söderström and Hedblom, 2007). Finally, radar tracking revealed that honeybees used gravel roads (and other linear features) for navigation (Menzel et al., 2019). Overall, evidence suggests that road verges can be used as corridors and roads as navigational aids by some larger pollinator taxa, but research is too limited in scope to draw general conclusions.

\subsection{Q3) How much do vehicle-pollinator collisions affect pollinators?}

Pollinators that attempt to cross roads at low heights may be killed by collision with vehicles. Few studies provide information on road crossing height, though Mora Alvarez et al. (2019) observed that most migrating monarch butterflies crossed highways at heights of $>6 \mathrm{~m}$, whilst other butterfly species have been observed exhibiting resourcesearching behaviour along roads (zig-zagging low to the ground) (Severns, 2008; Skórka et al., 2013), which puts them at high risk of being hit by road traffic. Most studies estimate mortality from vehiclepollinator collisions using counts of dead insects along roads, which are likely to underestimate (e.g. sampling is unlikely to find all individuals, especially those that become attached to vehicles, disintegrate, are eaten by scavengers, or are ricocheted or washed off the road) and may be subject to bias (e.g. detectability varies with road and verge surface and with the size of insect) (Munguira and Thomas, 1992; Skórka, 2016). Five studies broadly assess insect or animal roadkill, and include information on pollinator taxa, whilst 12 studies focus on butterflies (Table 1).

Overall, studies show that many pollinators are killed by collisions with vehicles across a wide range of road types and traffic volumes (Table 1). Average roadkill rates range from 0.45 to 10.1 roadkills $/ \mathrm{km} /$ day for Lepidoptera along diverse paved road types (Baxter-Gilbert et al., 2015; Keilsohn et al., 2018; Rao and Girish, 2007; Skórka et al., 2015) and 21.31 to 26.8 roadkills/km/day for Hymenoptera, but have only been measured along paved highways (Baxter-Gilbert et al., 2015; Keilsohn et al., 2018) (Table 1). However, the impact of roadkill at the population level is unclear. Relative (rather than absolute) roadkills, i.e. roadkills as a proportion of pollinators observed in the road verge, provides a better measure of the net impact of road verges on pollinators. Estimates of relative roadkill range from 0.6 to $7 \%$ of butterflies in road verges (Table 1 ) - which is an order of magnitude lower than the proportion of butterflies killed by predators and parasitoids, so probably having little impact on butterfly populations (Munguira and Thomas, 1992), but no estimates exist for other pollinator taxa. Ultimately, impacts of roadkill on pollinator populations are difficult to assess in the field, but could be estimated using population modelling.

Pollinator roadkill is often concentrated in spatial or temporal hotspots. For example, Skórka et al. (2015) found that $49 \%$ of butterfly roadkill was concentrated in hotspots that covered just $4 \%$ of total road length, and Baxter-Gilbert et al. (2015) recorded a bloom of bibionid flies in May (spring) of one study year, which resulted in 100 times more roadkill (1463 dipteran roadkills/km/day). Keilsohn et al. (2018) found that average insect roadkill was three to four times greater for roads adjacent to meadows and lawns than wooded areas, and more than double when there was a median strip (central vegetated strip separating the opposing lanes of traffic) (Table 1). Studies on the monarch butterfly also show that roadkill is concentrated in hotspots (Tracy et al., 2019), for example $>200,000$ monarchs were killed each year at two paved, rural highways (14,330/8862 vehicles/day) in Mexico that are known monarch roadkill hotspots due to their importance as migratory crossing locations (Mora Alvarez et al., 2019) (Table 1). Along the entire migratory route, monarch roadkill can be considerable - killing an estimated 2.1 million monarchs - equivalent to $3 \%$ of the overwintering population (Kantola et al., 2019). Overall, studies on butterflies have found that butterfly roadkill is greater for more mobile taxa and increases with traffic volumes and road width (Halbritter et al., 2015; Munguira and Thomas, 1992; Skórka et al., 2013, 2015) (Table 1).

\subsection{Q4) How much does road pollution affect pollinators?}

Pollinators in road verges are exposed to diverse forms of pollution from roads and road traffic, including light, noise, exhaust fumes and heavy metals. The risk of road pollution to pollinators depends both on their exposure and on the hazard that field-realistic levels pose. Whilst pollinators that feed in road verges might be exposed to road pollution for short durations, pollinators using road verges for nesting, as larval stages or that have low mobility, will be exposed over much longer durations. We found 28 studies that assess the exposure of pollinators and/or the associated hazard for specific forms of road pollution: light, noise, turbulence, exhaust fumes and metals (Table 2). Specifically, studies show that streetlights attract nocturnal pollinators from multiple taxa (Coleoptera, Diptera, Hymenoptera and Lepidoptera), diminish nearby moth communities and inhibit moth predator evasion behaviour (Table 2). Research for other forms of pollution is limited: noise and turbulence have been addressed in only one study each, heavy metal studies have only reported observed concentrations (exposure) but not the impact on pollinators (hazard), and four studies of air pollution show that vehicle exhaust fumes can degrade floral odours and subsequent detection and learning by honeybees but have not 


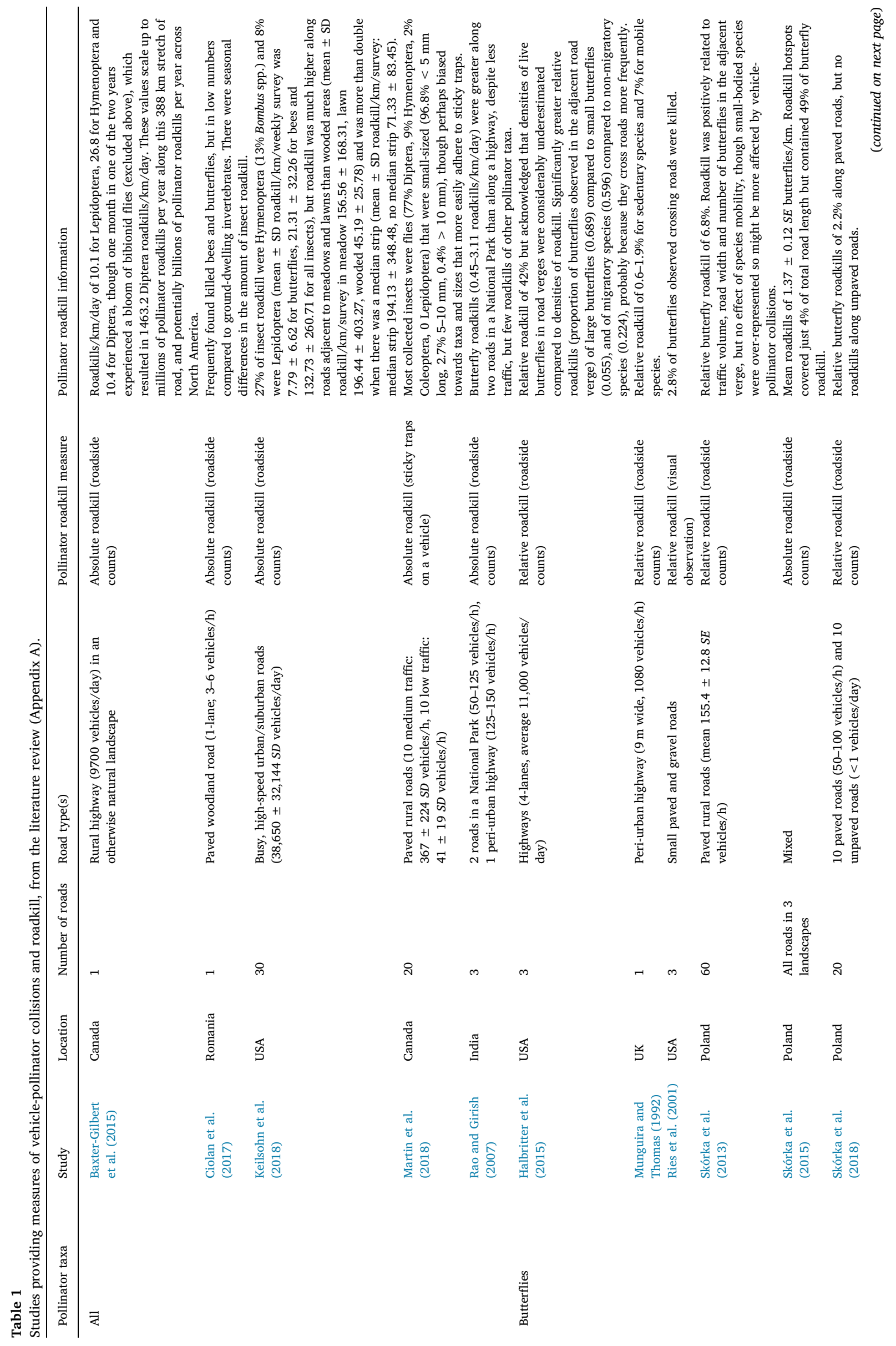


considered other pollinator taxa. Additionally, experimental studies have only assessed these forms of road pollution individually, most studies are limited to a single pollinator species and are often performed under laboratory conditions (Table 2), and several other forms of road pollution remain completely unstudied (e.g. vibration, particulate matter and nitrogen enrichment from vehicle emissions) (Table 2).

At a population and community level, road pollution might: (i) deter pollinators from road verges, especially highly mobile species and (ii) deplete local pollinator populations, especially less mobile species, due to direct (impacting pollinators) or indirect (e.g. impacting flowers) lethal or sublethal effects. Some observational studies have reported fewer pollinators closer to roads (Corcos et al., 2019; Phillips et al., 2019) and along roads with greater traffic densities (Martin et al., 2018; Phillips et al., 2019), where pollution is likely to be greater. Five studies on butterflies (Flick et al., 2012; Munguira and Thomas, 1992; Skórka et al., 2013, 2018; Valtonen et al., 2006b) and one on bees (Hopwood, 2008) found no such trends (Flick et al., 2012; Hopwood, 2008; Munguira and Thomas, 1992; Skórka et al., 2013, 2018) though most studies only measure and assess traffic volume as a covariate. Specifically, Martin et al. (2018) recorded an average of $23.5 \%$ fewer insects along medium-traffic $(367 \pm 224 S D$ vehicles/h) compared to lowtraffic (41 $\pm 19 S D$ vehicles/h) roads. Phillips et al. (2019) recorded an average of $61 \%$ fewer pollinators along high-traffic roads (1200-1400 vehicles/h) compared to low-traffic roads $(0-200$ vehicles/h) and (compared to $10 \mathrm{~m}$ from the road edge) $70 \%$ fewer pollinators $1 \mathrm{~m}$ from the road and $59 \%$ fewer pollinators $5 \mathrm{~m}$ from the road edge. Corcos et al. (2019) observed that tachinid fly density and species richness decreased with road proximity in urban areas. The potential drivers of these patterns are difficult to disentangle and could be due to pollinators being repelled by pollution, pollinator population being depleted by pollution, or confounding factors such as pollinator populations being depleted by vehicle-pollinator collisions or resource quality being lower closer to roads. Studies on honeybees have also found that hives closer to roads contained bees with greater wing shape asymmetry, perhaps due to air pollution because $\mathrm{CO}_{2}$ levels have been shown to affect wing asymmetry in a bumblebee species (Leonard et al., 2018), and that hives in a polluted area next to a busy trunk road had honeybees with activity of body surface enzymes that are important for combating disease and infection, whilst hives in a control area did not (Strachecka et al., 2012). Further research is needed to determine the singular and combined impacts of different forms of road pollution on pollinators, using field-realistic conditions and pollution levels.

\subsection{Q5) How does road verge management affect pollinators?}

In the first instance, road verge management can benefit pollinators by creating high-quality habitats in new verges and restoring and maintaining high-quality habitats in existing verges. Second, road verge management (e.g. mowing regime) can affect the capacity of road verge habitats to support pollinators. Whilst studies about grassland management were beyond the scope of the review, they are likely to be broadly relevant to road verge management, so we also signpost to some key studies.

\subsubsection{Habitat creation and restoration}

Studies about road verge habitat creation and restoration are limited in number, but studies in Iowa and Kansas, USA show that prairievegetation road verges are much better than weedy (dominated by nonnative vegetation) road verges for bees ( 2 times greater density and 1.5 times greater species richness of bees, despite little difference in floral density) (Hopwood, 2008) and better than weedy or grassy (low forb cover) verges for habitat-sensitive butterflies ( 5 times greater density, 2 times greater species richness) (Ries et al., 2001). Similarly, Valtonen et al. (2006a) found that road verges in Finland dominated by an invasive plant Lupinus polyphyllus had significantly fewer butterflies. More generally, a recent systematic review by Villemey et al. (2018) 


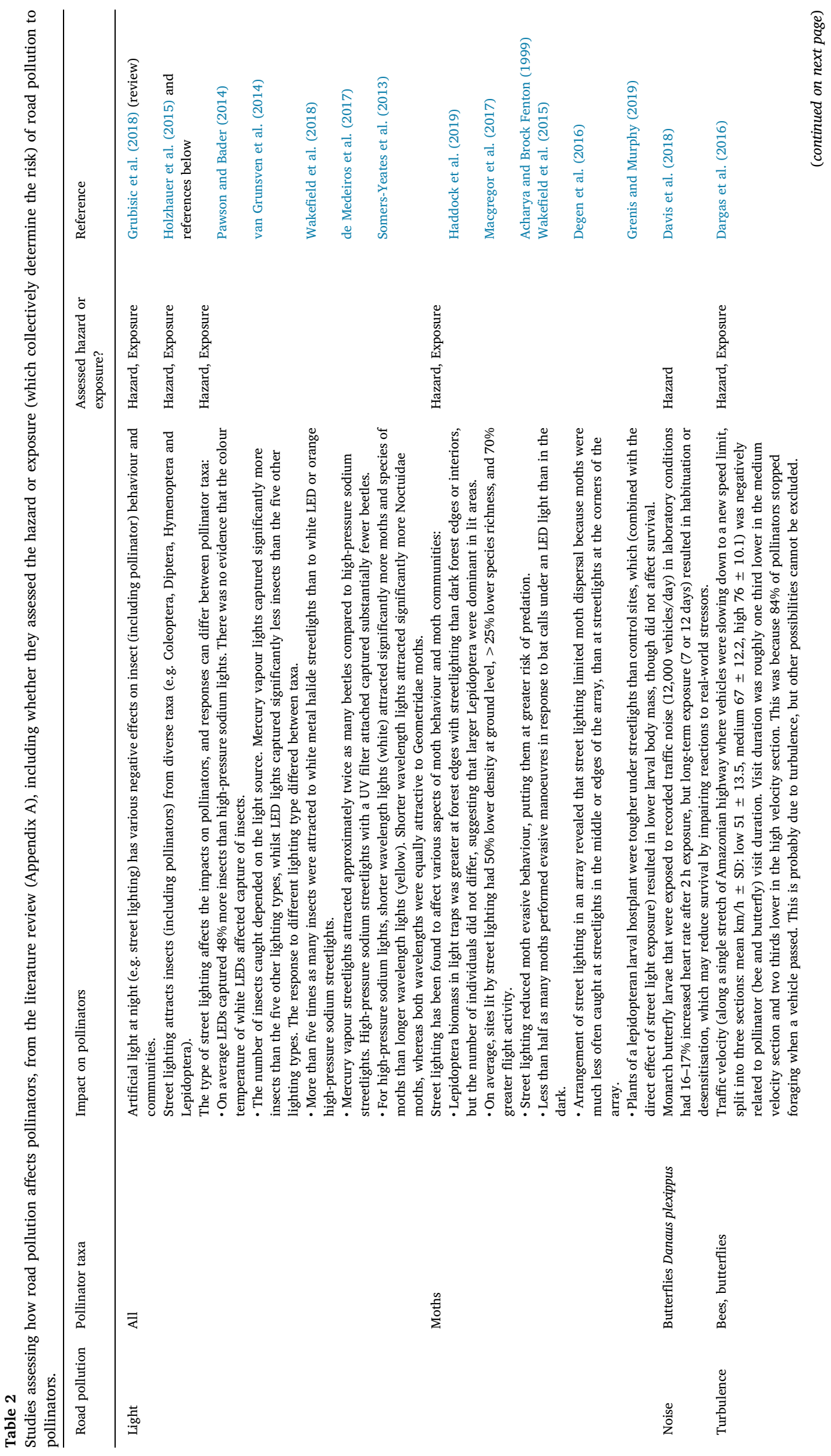




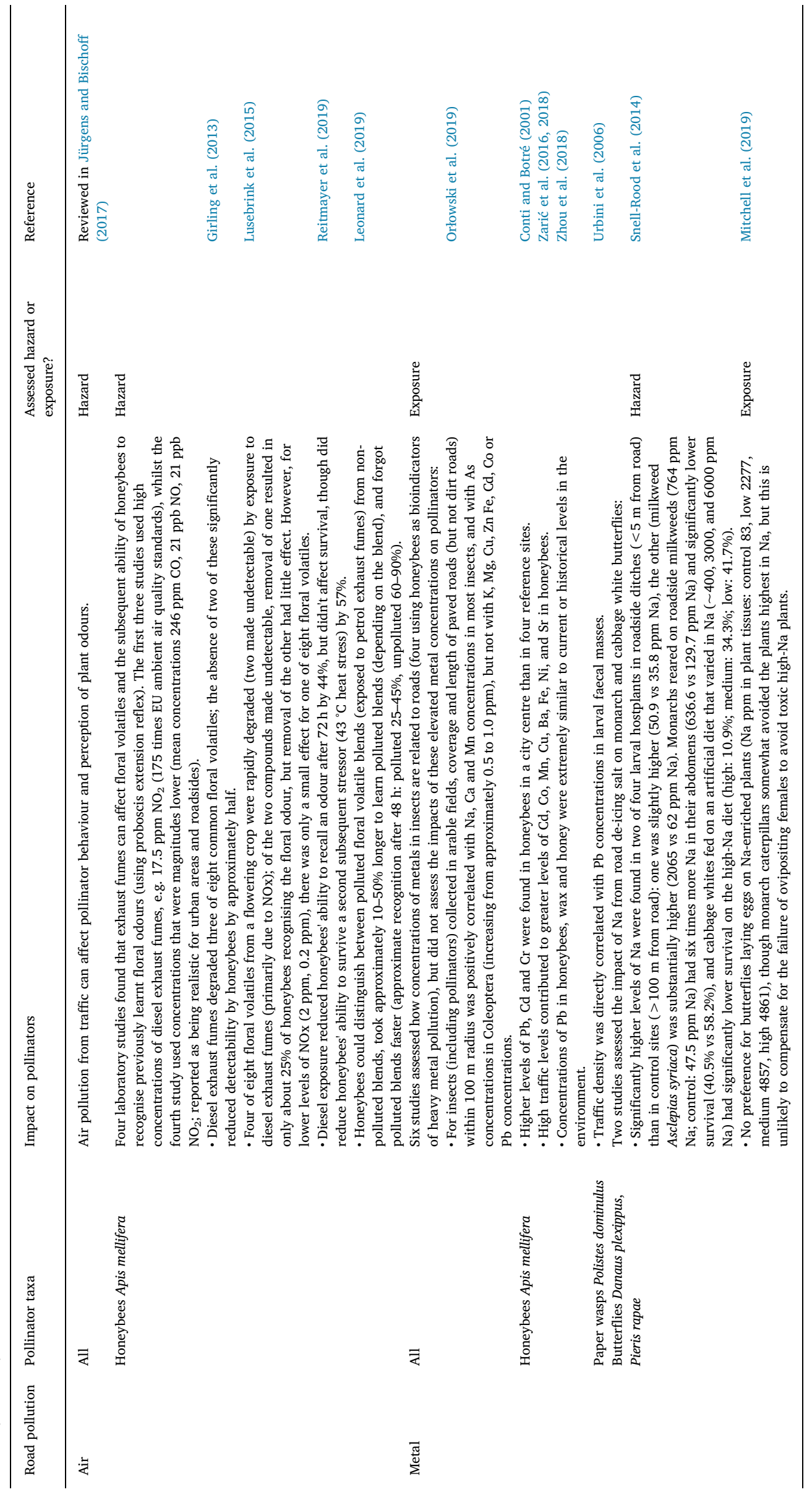


Table 3

A summary of current knowledge about pollinators and road verges, from the literature review (Appendix A). Confidence was based on the quantity, quality and consensus of evidence using a four-box model for the qualitative communication of certainty (IPBES, 2019). The definitions for categories are: (i) well established: comprehensive meta-analysis or other synthesis, or multiple independent studies that agree, (ii) established but incomplete: general agreement although only a limited number of studies exist but no comprehensive synthesis, and/or the studies that exist imprecisely address the question, (iii) unresolved: multiple independent studies exist but conclusions do not agree, and (iv) inconclusive: existing as or based on a suggestion or speculation, no or limited evidence (IPBES, 2019). A copy of the table is provided in Appendix D with references to the evidence for each statement.

\begin{tabular}{|c|c|c|c|}
\hline Topic & Conclusion & Confidence & Limitation(s) \\
\hline \multirow[t]{12}{*}{$\begin{array}{l}\text { Pollinator communities \& resources } \\
\text { in road verges }\end{array}$} & $\begin{array}{l}\text { Road verges are used by pollinators for... } \\
\text {...feeding }\end{array}$ & Well established & \\
\hline & ...reproduction & $\begin{array}{l}\text { Established but } \\
\text { incomplete }\end{array}$ & Studies limited to Lepidoptera \\
\hline & ...nesting & $\begin{array}{l}\text { Established but } \\
\text { incomplete }\end{array}$ & Four studies \\
\hline & ...overwintering & Inconclusive & A single study of a single site \\
\hline & $\begin{array}{l}\text { Road verges contain a similar or greater density and species } \\
\text { richness of pollinators and flowers to... }\end{array}$ & & \\
\hline & ...agricultural fields & Well established & \\
\hline & ...urban habitats & Unresolved & A single study \\
\hline & ...natural/semi-natural habitats & Well established & \\
\hline & $\begin{array}{l}\text { Road verges are used by pollinators for reproduction, nesting and } \\
\text { overwinter to a similar or greater extent than... }\end{array}$ & & \\
\hline & ...agricultural fields & Inconclusive & Three studies, limited to monarch butterflies \\
\hline & ...urban habitats & Inconclusive & No studies \\
\hline & ...natural/semi-natural habitats & Inconclusive & Five studies, mostly on monarch butterflies \\
\hline \multirow[t]{5}{*}{ Pollinator movement \& dispersal } & Roads are a... & & \\
\hline & $\begin{array}{l}\text {...minor, impermeable barrier to movement for larger pollinator } \\
\text { taxa }\end{array}$ & $\begin{array}{l}\text { Established but } \\
\text { incomplete }\end{array}$ & Studies mostly limited to Lepidoptera \\
\hline & ...major barrier to movement for smaller pollinator taxa & $\begin{array}{l}\text { Established but } \\
\text { incomplete }\end{array}$ & Four studies \\
\hline & $\begin{array}{l}\text { Road verges are corridors for movement and dispersal for some } \\
\text { pollinator taxa }\end{array}$ & Inconclusive & Five studies, but limited contexts \\
\hline & Roads/road verges are navigational aids for some pollinator taxa & Inconclusive & A single study on honeybees \\
\hline \multirow[t]{2}{*}{ Vehicle-pollinator collisions } & Vehicle-pollinator collisions kill pollinators & Well established & \\
\hline & $\begin{array}{l}\text { The benefits of road verges for pollinators outweigh the negative } \\
\text { impacts of roadkills }\end{array}$ & $\begin{array}{l}\text { Established but } \\
\text { incomplete }\end{array}$ & Studies limited to Lepidoptera \\
\hline \multirow[t]{8}{*}{ Road pollution } & Road pollution negatively affects pollinators in road verges & Well established & \\
\hline & $\begin{array}{l}\text { Pollinators in road verges are negatively affected by... } \\
\text {...light pollution }\end{array}$ & Well established & \\
\hline & ...noise pollution & Inconclusive & A single study \\
\hline & ...vibrations & Inconclusive & No studies \\
\hline & ...turbulence & Inconclusive & A single study \\
\hline & ...air pollution & $\begin{array}{l}\text { Established but } \\
\text { incomplete }\end{array}$ & Studies limited to honeybees \\
\hline & ...metal pollution & $\begin{array}{l}\text { Established but } \\
\text { incomplete }\end{array}$ & Studies limited to sodium and Lepidoptera \\
\hline & $\begin{array}{l}\text { The benefits of road verges for pollinators outweigh the negative } \\
\text { impacts of pollution }\end{array}$ & Inconclusive & Inferred, but no studies \\
\hline \multirow[t]{8}{*}{$\begin{array}{l}\text { Road verge, road \& landscape } \\
\quad \text { characteristics }\end{array}$} & $\begin{array}{l}\text { Road verges with higher quality habitat (e.g. greater plant species } \\
\text { richness, density and species richness of flowers)... }\end{array}$ & & \\
\hline & ...contain a greater density and species richness of pollinators & Well established & \\
\hline & ...have fewer pollinator road crossings and roadkills & $\begin{array}{l}\text { Established but } \\
\text { incomplete }\end{array}$ & Studies mostly on Lepidoptera \\
\hline & $\begin{array}{l}\text { Wider road verges contain a greater density and species richness } \\
\text { of pollinators }\end{array}$ & $\begin{array}{l}\text { Established but } \\
\text { incomplete }\end{array}$ & Studies mostly on Lepidoptera \\
\hline & Roads with greater traffic volumes have... & & \\
\hline & ...lower pollinator density in road verges & Unresolved & $\begin{array}{l}\text { Five studies (four on Lepidoptera) find no } \\
\text { effect }\end{array}$ \\
\hline & ...more pollinator roadkills & $\begin{array}{l}\text { Established but } \\
\text { incomplete }\end{array}$ & Three studies, limited to Lepidoptera \\
\hline & The composition of the surrounding landscape affect pollinator & Well established & Various effects \\
\hline
\end{tabular}


Table 3 (continued)

\begin{tabular}{|c|c|c|c|}
\hline Topic & Conclusion & Confidence & Limitation(s) \\
\hline \multirow[t]{22}{*}{ Road verge management } & $\begin{array}{l}\text { Road verges can be enhanced for pollinators through strategic } \\
\text { management }\end{array}$ & Well established & \\
\hline & Road verge mowing directly kills pollinators, eggs and larvae & Inconclusive & No studies \\
\hline & Road verge mowing regime affects... & & \\
\hline & ...flower density and species richness & Well established & \\
\hline & ...the availability and suitability of larval hostplants & $\begin{array}{l}\text { Established but } \\
\text { incomplete }\end{array}$ & Studies limited to monarch butterflies \\
\hline & ...pollinator density and species richness & Well established & \\
\hline & ...use of road verges for pollinator movement and dispersal & Inconclusive & No studies \\
\hline & ...pollinator road crossing & Inconclusive & Inferred, but no studies \\
\hline & ...pollinator roadkill & $\begin{array}{l}\text { Established but } \\
\text { incomplete }\end{array}$ & Inferred, but two studies on Lepidoptera \\
\hline & Pollinator communities in road verges benefit from... & & \\
\hline & ...creating high quality habitats on new road verges & Well established & \\
\hline & ...controlling/removing invasive, non-native plant species & $\begin{array}{l}\text { Established but } \\
\text { incomplete }\end{array}$ & Three studies, but limited contexts \\
\hline & ...reducing mowing frequency to $0-2$ cuts/year & $\begin{array}{l}\text { Established but } \\
\text { incomplete }\end{array}$ & Inferred, but a single study \\
\hline & ...avoiding mowing during summer & Unresolved & Disagreement between studies \\
\hline & ...removing cuttings & Inconclusive & A single study \\
\hline & ...leaving some areas unmown & $\begin{array}{l}\text { Established, but } \\
\text { incomplete }\end{array}$ & Inferred, but a single study \\
\hline & ...using mosaic mowing/management & Inconclusive & Inferred, but a single study \\
\hline & ...creating habitat diversity across the road network & Inconclusive & Inferred, but no studies \\
\hline & $\begin{array}{l}\text {...identifying pollinator roadkill hotspots and applying reduction } \\
\text { measures }\end{array}$ & Inconclusive & Inferred, but no studies \\
\hline & ...reducing impacts of street lighting & Well established & \\
\hline & $\begin{array}{l}\text {...prioritising enhancement of road verges with the greatest } \\
\text { capacity to benefit pollinators }\end{array}$ & Inconclusive & Inferred, but no studies \\
\hline & $\begin{array}{l}\text { Monarch butterflies benefit from mowing road verges around } \\
\text { mid-July }\end{array}$ & Well established & \\
\hline Overall & $\begin{array}{l}\text { The benefits of road verges as habitats and corridors for } \\
\text { pollinators outweigh the costs of vehicle-pollinator collisions and } \\
\text { pollution. }\end{array}$ & $\begin{array}{l}\text { Established but } \\
\text { incomplete }\end{array}$ & $\begin{array}{l}\text { Large-scale modelling studies are needed to } \\
\text { collectively assess the benefits and costs }\end{array}$ \\
\hline
\end{tabular}

concluded that management of verges aimed at restoring natural or semi-natural vegetation types had positive to neutral effects on insect biodiversity.

\subsubsection{Mowing regimes}

Recommendations for mowing frequency vary from 0 to 2 cuts per year, though optimum management differs among pollinator taxa. Most studies focus on butterflies, though two studies consider entire pollinator communities. An observational study of 19 road verges in the UK found that mown verges (cut once between May and August, cuttings not removed) had on average $67 \%$ fewer flowers and $61 \%$ fewer pollinators across the summer than unmown verges (Phillips et al., 2019). Noordijk et al. (2009) experimentally manipulated mowing frequency (cuts/year: 0, 1 (early autumn) or 2 (early summer and early autumn)) and removal of cuttings (left in the verge or removed) in a single road verge (with a species-rich plant community) in the Netherlands. Increasing the number of cuts from 0 to 1 cut resulted in 3.5 times greater flower density and 2 times greater flower species richness, but no significant effect on pollinator density, though increasing from 1 to 2 cuts/ year resulted in 3.5 times greater pollinator density. Two cuts per year combined with removal of cuttings resulted in the greatest flower density, flower species richness and pollinator density, though removal of cuttings by itself generally did not result in significant increases. More generally, systematic reviews have found a greater plant species richness (which is likely to benefit pollinators) in road verges mowed once or twice per year with removal of cuttings than in unmown verges (Jakobsson et al., 2018) and in European meadows where mowing was delayed from spring to summer (whilst delaying from spring to fall or from early summer to later in the season had a negative effect; Humbert et al., 2012), though another review for European semi-natural grasslands found relatively little effect of mowing frequency on biodiversity (Tälle et al., 2018). However, none of these studies account for the direct mortality of pollinators, eggs and larvae during mowing. No studies have assessed pollinator mortality during mowing specifically for road verges, but an experiment in fields of Phacelia tanacetifolia and fields of Trifolium repens found that honeybees did not avoid approaching mowing machinery, so many honeybees were killed or injured, though the proportion killed was strongly affected by the type of mowing machinery (Fluri and Frick, 2002).

Other studies are limited to Lepidoptera but provide evidence that they benefit from low mowing frequencies, delaying mowing until late summer and only partially mowing verges. Two large-scale field experiments assessed optimum mowing regimes for butterflies. In Florida, USA, Halbritter et al. (2015) found that mowing every 3 weeks resulted in 0.5 times lower flower density and 0.25 times lower flower species richness than mowing every 6 weeks or not mowing, but little difference in butterfly density (though the unmown treatment yielded the greatest number of butterflies from August onwards). In southern Finland, Valtonen et al. (2006b) found that partially-mown verges (where a substantial part of the verge always remained unmown) had double the butterfly density, 1.3 times greater butterfly species richness and 1.6 times greater diurnal moth species richness than early-summer mown verges; whilst late-summer mown verges showed intermediate results. Similarly, two further studies in southern Finland observed greater butterfly densities in road verges that are unmown, or otherwise mown in late summer (Valtonen and Saarinen, 2005) or mown no more than once or twice per year (Saarinen et al., 2005), and others have observed that verge mowing is followed by declines in butterfly densities (Haaland, 2015; Munguira and Thomas, 1992).

Studies focusing on single pollinator species can provide contradictory management recommendations. Field experiments exploring mowing regimes for monarch butterflies found that mowing spurred a regrowth of milkweed, which increased egg laying and extended the monarch breeding season compared to unmown controls, and that 


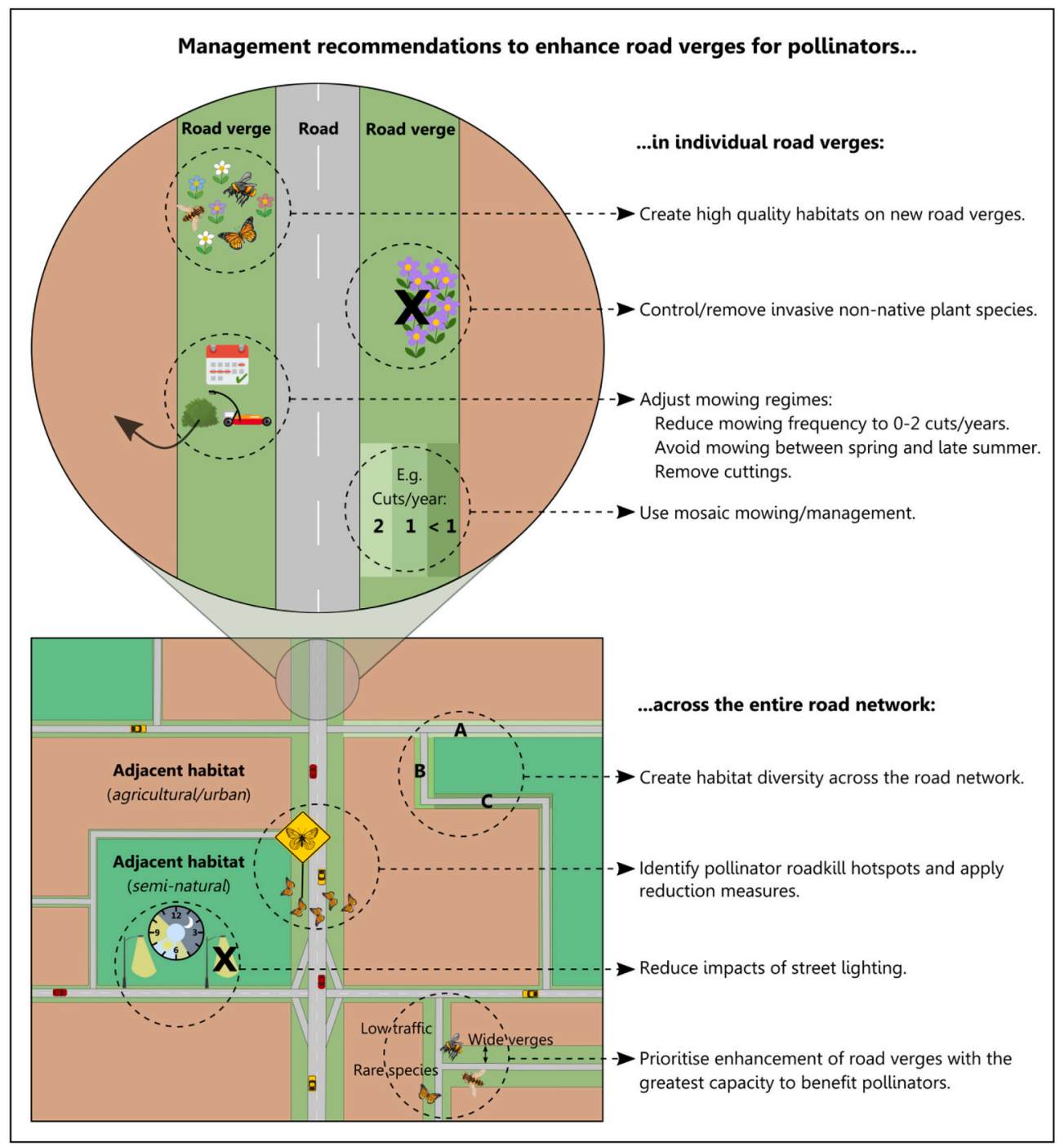

Fig. 3. Management recommendations for enhancing road verges for pollinators, based on the findings of the literature review.

mowing around mid-July was best, whilst mowing in August was too late for milkweeds to recover (Fischer et al., 2015; Knight et al., 2019). By contrast, a study of large blue butterflies Phengaris spp. (specialist brood parasites of ants that rely on a single hostplant species) found that mowing between mid-June and mid-September destroyed the locations with both host ants and flowering hostplants, whilst no mowing was also detrimental, and that some Phengaris spp. benefited most from early mowing but others from late mowing (Wynhoff et al., 2011). These studies demonstrate that bespoke management is needed when targeting a specific pollinator species of conservation concern.

\subsubsection{Management to reduce vehicle-pollinator collisions}

Studies suggest that improving the quality of road verge habitats can reduce butterfly road crossing (Polic et al., 2014; Ries et al., 2001) and roadkills (Skórka et al., 2013, 2015), though research is absent for other pollinator taxa. For example, Skórka et al. (2013) found that butterfly roadkills increased with the amount of verge mowing and that relative roadkills (roadkills as a proportion of the butterflies observed in the road verge) decreased with increasing plant species richness in the adjacent road verge. Ries et al. (2001) found that a much lower proportion of butterflies in higher quality prairie verges crossed roads (23\%) than butterflies in grassy (low forb cover) verges (49\%), which resulted in half as many relative roadkills. Two studies found no such effects (Halbritter et al., 2015; Valtonen and Saarinen, 2005), whilst one study found the opposite, but focused on a single rare butterfly species (Speyeria zerene hippolyta) along a single road (Zielin et al., 2016). Various other methods might be used to reduce pollinator roadkills (e.g. traffic speed restrictions) but have not been studied, though Zielin et al. (2016) found that $3 \mathrm{~m}$ high nets arranged parallel to the road were ineffective at increasing butterfly flight height over roads.

3.6. Q6) How do road verge, road and landscape characteristics affect pollinators in road verges?

Beyond management, other factors affect how good individual road verges are for pollinators, and their relative importance within the wider landscape, namely the characteristics of the road verge (e.g. verge width, aspect), the road (e.g. width, traffic volume) and the landscape (e.g. adjacent land-use). The effects of these road verge, road and landscape characteristics on pollinators in road verges are synthesised in Appendix C, summarised here, and must all be considered to optimise large-scale management of road verges for pollinators (e.g. where to prioritise enhancements). The most important factors are as follows. (i) Road verge habitat quality: higher quality road verge habitats support richer pollinator communities; specifically, the density of flowers and larval plants, and the species richness of flowers and plants often positively relate to pollinator density and species richness (e.g. 


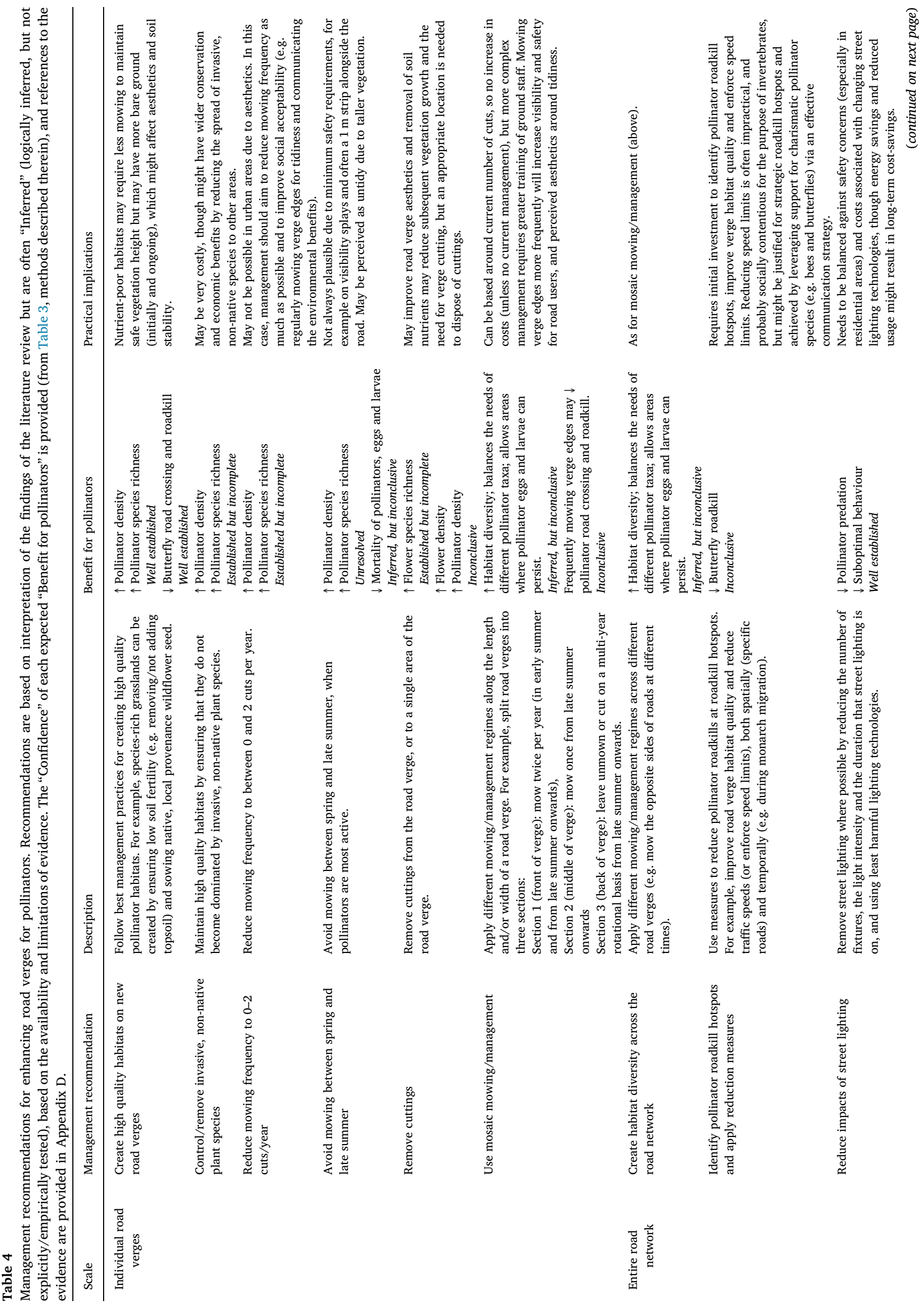


Hopwood, 2008; Phillips et al., 2019; Ries et al., 2001), and some studies on butterflies show that higher quality road verge habitats can reduce road crossing and roadkills (e.g. Ries et al., 2001; Skórka et al., 2013, 2015). (ii) Road verge width: wider road verges, which provide greater total habitat area and areas at greater distance from the road, often contain greater Lepidoptera density and species richness (e.g. Munguira and Thomas, 1992; Skórka et al., 2013). (iii) Traffic volume: some studies report fewer pollinators along roads with greater traffic volumes (Martin et al., 2018; Phillips et al., 2019), and traffic volume increases butterfly roadkills (Skórka et al., 2013, 2015, 2018). (iv) Surrounding landscape: road verges that are near higher quality pollinator habitats (e.g. semi-natural grasslands) often have more pollinators (e.g. Flick et al., 2012; Öckinger and Smith, 2007) and subsequently more pollinator roadkills (e.g. Keilsohn et al., 2018; Skórka et al., 2015), though pollinators are probably more dependent on road verges in landscapes with few high-quality habitats (e.g. intensive agricultural landscapes) (Phillips et al., 2019).

\section{Synthesis \& agenda for future research}

Road verges have considerable potential to be used for pollinator conservation, given the significant areas that they collectively cover (e.g. an estimated $1 \%$ of UK land). Growing societal interest in managing road verges for nature (especially pollinators) has provided an immediate need for evidence to inform management. This literature review has assessed the potential benefits of road verges for pollinators (as habitats and corridors), the potential negative impacts of roads (pollution and vehicle-pollinator collisions), and the impacts of road verge management. Based on the literature review, we provide a list of conclusions about pollinators and road verges, and information about the confidence and limitations of support for each conclusion (Table 3). Overall, the literature review demonstrated that: (i) road verges are often hotspots of flowers and pollinators (well established), (ii) traffic and road pollution can cause mortality and other negative impacts on pollinators (well established), but available evidence suggests that the benefits of road verges to pollinators far outweigh the costs (established but incomplete), and (iii) road verges can be enhanced for pollinators through strategic management (well established). During the review, we have identified key research gaps. In general, there is a scarcity of research outside of Europe and North America, and on non-grassland road verge habitats, entire pollinator communities and pollinator taxa other than butterflies. Specifically, we propose seven priority questions for future research:

1. To what extent do pollinators use road verges for reproduction, nesting and overwintering, relative to other habitats?

2. To what extent do pollinators use road verges as corridors for movement and dispersal?

3. What is the combined impact of the diverse forms of road pollution on pollinators?

4. To what extent does mowing directly kill pollinators, eggs and larvae?

5. What are the population-level impacts of vehicle-pollinator collisions, pollution and different road verge management options?

6. Do road verges ever constitute an ecological trap for pollinators, and if so, under what circumstances?

7. What management strategies can be used to reduce pollinator roadkill and impacts of road pollution?

Furthermore, our approach provides a framework (Fig. 1) from which future research can explore and address issues relating to using road verges for nature conservation for other taxa.

\section{Management recommendations}

Finally, we consider what might be done to enhance road verges for 
pollinators. The characteristics of road verges (e.g. verge width), roads (e.g. traffic volumes) and the surrounding landscape (e.g. availability of semi-natural habitats) affect the capacity and importance of road verges for supporting pollinators. Therefore, management needs to consider both management of road verges per se (e.g. optimised mowing regimes), as well as strategic management of the road verge network as a whole (e.g. creating habitat diversity across the whole road network, and prioritising enhancement of road verges with the greatest capacity to benefit pollinators based on the type of road verge, road and composition of the surrounding landscape). We provide a general set of management recommendations in Fig. 3, incorporating the full range of topics that have been covered in the review, alongside practical considerations such as safety, costs and implementation of road verge management for pollinators in Table 4, as these will ultimately affect the acceptability and uptake of recommendations. Here, we describe three illustrative examples of management recommendations that are most strongly supported by the literature review.

First, management should aim to create high quality habitats on new and existing road verges by following best management practices, for example creating species-rich grassland by ensuring low soil fertility (e.g. removing/not adding topsoil) and sowing local provenance wildflower seed. This can increase pollinator density and species richness (well established) and reduce butterfly road crossing and roadkill (well established) (Table 4). From a practical perspective, nutrient-poor habitats may require less mowing to maintain safe vegetation height, but a greater cover of bare ground may affect aesthetics and soil stability. Second, management of frequently mown areas should be reduced where possible to $0-2$ cuts per year to allow wildflowers and larval foodplants to grow and to reduce the risk of direct mortality of pollinators and their eggs and larvae. Doing so can increase pollinator density and species richness (established but incomplete) (Table 4). Whilst this may be socially contentious in urban areas due to aesthetics, management should aim to reduce mowing frequency as far as possible and to improve acceptability of reduced mowing, for example by regularly mowing verge edges for tidiness and communicating the environmental benefits to the public. Third, impacts of street lighting should be reduced where possible by removing fixtures, reducing durations that fixtures are active, or otherwise by using the least harmful lighting technologies. This will reduce attraction of nocturnal pollinators and associated predation and impacts on pollinator communities (well established) (Table 4), but needs to be balanced against safety concerns, especially in residential areas, as well as costs associated with changing street lighting technologies; though energy savings and reduced usage might result in long-term cost-savings.

Overall, management recommendations for pollinators need to be balanced against requirements of other taxa (e.g. for important speciesrich plant communities, it may not be desirable to leave areas uncut; Jakobsson et al., 2018). Furthermore, bespoke management is recommended for road verges of particular conservation interest, based around specific habitat requirements (e.g. phenology and hostplants of the pollinator species). Finally, a strong environmental, social and financial case for investment in enhancing road verges for nature could be made by taking into consideration the benefits that people derive from pollinators and other forms of nature in road verges (Phillips et al., 2020) and by leveraging public support for the conservation of charismatic pollinator species (e.g. bees and butterflies).

Supplementary data to this article can be found online at https:// doi.org/10.1016/j.biocon.2020.108687.

\section{CRediT authorship contribution statement}

Benjamin B. Phillips: Conceptualization, Methodology, Investigation, Visualization, Formal analysis, Writing - original draft, Writing - review \& editing, Project administration. Claire
Wallace: Investigation, Writing - review \& editing. Bethany R. Roberts: Conceptualization, Investigation, Writing - review \& editing. Andrew T. Whitehouse: Conceptualization, Writing - review \& editing. Kevin J. Gaston: Writing - review \& editing. James M. Bullock: Methodology, Writing - review \& editing. Lynn V. Dicks: Methodology, Writing - review \& editing. Juliet L. Osborne: Methodology, Writing - review \& editing, Supervision.

\section{Declaration of competing interest}

The authors declare that they have no known competing financial interests or personal relationships that could have appeared to influence the work reported in this paper.

\section{Acknowledgements}

We would like to thank Ros Shaw and Craig Macadam for commenting on drafts of the manuscript. The project was conceived by BP and BR whilst writing a related report for Buglife (https://www.buglife. org.uk/managing-road-verges-for-pollinators), with whom BR was undertaking a work placement.

\section{Funding}

BBP was funded by a NERC GW4 + Doctoral Training Partnership (DTP) studentship from the Natural Environment Research Council (NERC) [NE/L002434/1], with additional funding from the Cornwall Area of Outstanding Natural Beauty unit. CW was funded by a NERC EnvEast DTP [NE/L002582/1]. LVD is funded by NERC [NE/N014472/ $1]$.

\section{Data availability statement}

All data supporting the results are provided in the manuscript and appendices, and were gathered from the associated references.

\section{References}

Acharya, L., Brock Fenton, M., 1999. Bat attacks and moth defensive behaviour around street lights. Can. J. Zool. 77, 27-33. https://doi.org/10.1139/cjz-77-1-27.

Andersson, P., Koffman, A., Sjödin, N.E., Johansson, V., 2017. Roads may act as barriers to flying insects: species composition of bees and wasps differs on two sides of a large highway. Nat. Conserv. 18, 47-59. https://doi.org/10.3897/natureconservation.18. 12314.

Baldock, K.C.R., Goddard, M.A., Hicks, D.M., Kunin, W.E., Mitschunas, N., Morse, H., Osgathorpe, L.M., Potts, S.G., Robertson, K.M., Scott, A.V., Staniczenko, P.P.A., Stone, G.N., Vaughan, I.P., Memmott, J., 2019. A systems approach reveals urban pollinator hotspots and conservation opportunities. Nat. Ecol. Evol. 3, 363-373. https://doi.org/10.1038/s41559-018-0769-y.

Baxter-Gilbert, J.H., Riley, J.L., Neufeld, C.J.H., Litzgus, J.D., Lesbarrères, D., 2015. Road mortality potentially responsible for billions of pollinating insect deaths annually. J. Insect Conserv. 19, 1029-1035. https://doi.org/10.1007/s10841-015-9808-z.

Berg, Å., Ahrné, K., Öckinger, E., Svensson, R., Söderström, B., 2011. Butterfly distribution and abundance is affected by variation in the Swedish forest-farmland landscape. Biol. Conserv. 144, 2819-2831. https://doi.org/10.1016/j.biocon.2011.07.035.

Bhattacharya, M., Primack, R.B., Gerwein, J., 2003. Are roads and railroads barriers to bumblebee movement in a temperate suburban conservation area. Biol. Conserv. 109, 37-45. https://doi.org/10.1016/S0006-3207(02)00130-1.

Brunzel, S., Elligsen, H., Frankl, R., 2004. Distribution of the Cinnabar moth Tyria jacobaeae $\mathrm{L}$. at landscape scale: use of linear landscape structures in egg laying on larval hostplant exposures. Landsc. Ecol. 19, 21-27. https://doi.org/10.1023/B:LAND. 0000018354.77405.0e.

Buglife, 2020. Managing Road Verges for Pollinators [WWW Document]. URL. https:// www.buglife.org.uk/resources/habitat-management/managing-road-verges-forpollinators/.

Butterfly Conservation, 2020. Building Sites for Butterflies [WWW Document]. URL. https://butterfly-conservation.org/our-work/conservation-projects/building-sitesfor-butterflies.

Central Intelligence Agency, U, 2017. The World Fact Book [WWW Document]. URL https://www.cia.gov/library/publications/the-world-factbook/index.html.

Chapman, J.W., Drake, V.A., Reynolds, D.R., 2011. Recent insights from radar studies of 
insect flight. Annu. Rev. Entomol. 56, 337-356. https://doi.org/10.1146/annurevento-120709-144820.

Ciolan, E., Cicort-Lucaciu, A.Ş., Sas-Kovács, I., Ferenţi, S., Covaciu-Marcov, S.D., 2017. Wooded area, forest road-killed animals: intensity and seasonal differences of road mortality on a small, newly upgraded road in western Romania. Transp. Res. Part D Transp. Environ. 55, 12-20. https://doi.org/10.1016/j.trd.2017.06.014.

Cole, L.J., Brocklehurst, S., Robertson, D., Harrison, W., McCracken, D.I., 2017. Exploring the interactions between resource availability and the utilisation of semi-natural habitats by insect pollinators in an intensive agricultural landscape. Agric. Ecosyst. Environ. 246, 157-167. https://doi.org/10.1016/j.agee.2017.05.007.

Conti, M., Botré, F., 2001. Honeybees and their products as potential bioindicators of heavy metal contamination. Environ. Monit. Assess. 69, 267-282. https://doi.org/10. 1023/A:1010719107006.

Corcos, D., Cerretti, P., Caruso, V., Mei, M., Falco, M., Marini, L., 2019. Impact of urbanization on predator and parasitoid insects at multiple spatial scales. PLoS One 14, 1-15. https://doi.org/10.1371/journal.pone.0214068.

Daniels, J., Kimmel, C., McClung, S., Epstein, S., Bremer, J., Rossetti, K., 2018. Better understanding the potential importance of Florida roadside breeding habitat for the monarch. Insects 9, 137. https://doi.org/10.3390/insects9040137.

Dargas, J.H.F., Chaves, S.R., Fischer, E., 2016. Pollination of lark daisy on roadsides declines as traffic speed increases along an Amazonian highway. Plant Biol. 18, 542-544. https://doi.org/10.1111/plb.12437.

Davis, A.K., Schroeder, H., Yeager, I., Pearce, J., 2018. Effects of simulated highway noise on heart rates of larval monarch butterflies, Danaus plexippus: implications for roadside habitat suitability. Biol. Lett. 14, 20180018. https://doi.org/10.1098/rsbl. 2018.0018.

de Medeiros, B.A.S., Barghini, A., Antonio, S., 2017. Streetlights attract a broad array of beetle species. Rev. Bras. Entomol. 61, 74-79. https://doi.org/10.1016/j.rbe.2016. 11.004.

Degen, T., Mitesser, O., Perkin, E.K., Weiß, N.S., Oehlert, M., Mattig, E., Hölker, F., 2016. Street lighting: sex-independent impacts on moth movement. J. Anim. Ecol. 85, 1352-1360. https://doi.org/10.1111/1365-2656.12540.

Fischer, S.J., Williams, E.H., Brower, L.P., Palmiotto, A., 2015. Enhancing monarch butterfly reproduction by mowing fields of common milkweed. Am. Midl. Nat. 173, 229-240. https://doi.org/10.1674/amid-173-02-229-240.1.

Flick, T., Feagan, S., Fahrig, L., 2012. Effects of landscape structure on butterfly species richness and abundance in agricultural landscapes in eastern Ontario, Canada. Agric. Ecosyst. Environ. 156, 123-133. https://doi.org/10.1016/j.agee.2012.05.006.

Fluri, P., Frick, R., 2002. Honey bee losses during mowing of flowering fields. Bee World 83, 109-118. https://doi.org/10.1080/0005772X.2002.11099550.

Forman, R.T.T., Sperling, D., Bissonette, J.A., Clevenger, A.P., Cutshall, C.D., Dale, V.H., Fahrig, L., France, R.L., Goldman, C.R., Heanue, K., Jones, J., Swanson, F, Turrentine, T., Winter, T.C., 2003. Road Ecology. Island Press.

Franzén, M., Larsson, M., Nilsson, S.G., 2009. Small local population sizes and high habitat patch fidelity in a specialised solitary bee. J. Insect Conserv. 13, 89-95. https:// doi.org/10.1007/s10841-007-9123-4.

Gardiner, M.M., Riley, C.B., Bommarco, R., Öckinger, E., 2018. Rights-of-way: a potential conservation resource. Front. Ecol. Environ. 16, 149-158. https://doi.org/10.1002/ fee.1778.

Girling, R.D., Lusebrink, I., Farthing, E., Newman, T.A., Poppy, G.M., 2013. Diesel exhaust rapidly degrades floral odours used by honeybees. Sci. Rep. 3, 2779. https:// doi.org/10.1038/srep02779.

Goodwin, C., Keep, B., Leather, S.R., 2017. Habitat richness and tree species richness of roundabouts: effects on site selection and the prevalence of arboreal caterpillars. Urban Ecosyst. 20, 889-895. https://doi.org/10.1007/s11252-017-0644-7.

Grant, T.J., Parry, H.R., Zalucki, M.P., Bradbury, S.P., 2018. Predicting monarch butterfly (Danaus plexippus) movement and egg-laying with a spatially-explicit agent-based model: the role of monarch perceptual range and spatial memory. Ecol. Model. 374, 37-50. https://doi.org/10.1016/j.ecolmodel.2018.02.011.

Greenleaf, S.S., Williams, N.M., Winfree, R., Kremen, C., 2007. Bee foraging ranges and their relationship to body size. Oecologia 153, 589-596. https://doi.org/10.1007/ s00442-007-0752-9.

Grenis, K., Murphy, S.M., 2019. Direct and indirect effects of light pollution on the performance of an herbivorous insect. Insect Sci. 26, 770-776. https://doi.org/10.1111/ 1744-7917.12574.

Grubisic, M., van Grunsven, R.H.A., Kyba, C.C.M., Manfrin, A., Hölker, F., 2018. Insect declines and agroecosystems: does light pollution matter? Ann. Appl. Biol. 173, 180-189. https://doi.org/10.1111/aab.12440.

Haaland, C., 2015. Abundances and movement of the Scarce Copper butterfly (Lycaena virgaureae) on future building sites at a settlement fringe in southern Sweden. J. Insect Conserv. 19, 255-264. https://doi.org/10.1007/s10841-014-9708-7.

Haddock, J.K., Threlfall, C.G., Law, B., Hochuli, D.F., 2019. Light pollution at the urban forest edge negatively impacts insectivorous bats. Biol. Conserv. 236, 17-28. https:// doi.org/10.1016/j.biocon.2019.05.016.

Halbritter, D.A., Daniels, J.C., Whitaker, D.C., Huang, L., 2015. Reducing mowing frequency increases floral resource and butterfly (Lepidoptera: Hesperioidea and Papilionoidea) abundance in managed roadside margins. Florida Entomol. 98 1081-1092. https://doi.org/10.1653/024.098.0412.

Hale, R., Swearer, S.E., 2016. Ecological traps: current evidence and future directions. Proc. R. Soc. B Biol. Sci. 283, 1-8. https://doi.org/10.1098/rspb.2015.2647.

Hall, M.A., Nimmo, D.G., Cunningham, S.A., Walker, K., Bennett, A.F., 2019. The response of wild bees to tree cover and rural land use is mediated by species' traits. Biol. Conserv. 231, 1-12. https://doi.org/10.1016/j.biocon.2018.12.032.
Hanley, M.E., Wilkins, J.P., 2015. On the verge? Preferential use of road-facing hedgerow margins by bumblebees in agro-ecosystems. J. Insect Conserv. 19, 67-74. https://doi. org/10.1007/s10841-014-9744-3.

Hanula, J.L., Ulyshen, M.D., Horn, S., 2016. Conserving pollinators in North American forests: a review. Nat. Areas J. 36, 427-439. https://doi.org/10.3375/043.036.0409.

Hartzler, R.G., Buhler, D.D., 2000. Occurrence of common milkweed (Asclepias syriaca) in cropland and adjacent areas. Crop Prot. 19, 363-366. https://doi.org/10.1016/ S0261-2194(00)00024-7.

Helldin, J.-O., Wissman, J., Lennartsson, T., 2015. Abundance of red-listed species in infrastructure habitats - "responsibility species" as a priority-setting tool for transportation agencies' conservation action. Nat. Conserv. 11, 143-158. https://doi.org/ 10.3897/natureconservation.11.4433.

Heneberg, P., Bogusch, P., Řezáč, M., 2017. Roadside verges can support spontaneous establishment of steppe-like habitats hosting diverse assemblages of bees and wasps (Hymenoptera: Aculeata) in an intensively cultivated central European landscape. Biodivers. Conserv. 26, 843-864. https://doi.org/10.1007/s10531-016-1275-7.

Highways England, 2019. Boost for Bees and Safer, Smoother Journeys in A66 Upgrade [WWW Document]. URL. https://www.gov.uk/government/news/boost-for-beesand-safer-smoother-journeys-in-a66-upgrade.

Hill, B., Bartomeus, I., 2016. The potential of electricity transmission corridors in forested areas as bumblebee habitat. R. Soc. Open Sci. 3, 160525. https://doi.org/10.1098/ rsos. 160525 .

Holzhauer, S.I.J., Franke, S., Kyba, C.C.M., Manfrin, A., Klenke, R., Voigt, C.C., Lewanzik, D., Oehlert, M., Monaghan, M.T., Schneider, S., Heller, S., Kuechly, H., Brüning, A., Honnen, A.C., Hölker, F., 2015. Out of the dark: establishing a large-scale field experiment to assess the effects of artificial light at night on species and food webs. Sustain. 7, 15593-15616. https://doi.org/10.3390/su71115593.

Hopwood, J.L., 2008. The contribution of roadside grassland restorations to native bee conservation. Biol. Conserv. 141, 2632-2640. https://doi.org/10.1016/j.biocon. 2008.07.026.

Humbert, J.-Y., Pellet, J., Buri, P., Arlettaz, R., 2012. Does delaying the first mowing date benefit biodiversity in meadowland? Environ. Evid. 1, 9. https://doi.org/10.1186/ 2047-2382-1-9.

IPBES, 2019. The Global Assessment Report on Biodiversity and Ecosystem Services of the Intergovernmental Science-Policy Platform on Biodiversity and Ecosystem Services.

Jakobsson, S., Bernes, C., Bullock, J.M., Verheyen, K., Lindborg, R., 2018. How does roadside vegetation management affect the diversity of vascular plants and invertebrates? A systematic review. Environ. Evid. 7, 1-14. https://doi.org/10.1186/ s13750-018-0129-z.

Jansen, S.H.D.R., Holmgren, M., van Langevelde, F., Wynhoff, I., 2012. Resource use of specialist butterflies in agricultural landscapes: conservation lessons from the butterfly Phengaris (Maculinea) nausithous. J. Insect Conserv. 16, 921-930. https://doi. org/10.1007/s10841-012-9479-y.

Johansson, V., Koffman, A., Hedblom, M., Deboni, G., Andersson, P., 2018. Estimates of accessible food resources for pollinators in urban landscapes should take landscape friction into account. Ecosphere 9. https://doi.org/10.1002/ecs2.2486.

Jürgens, A., Bischoff, M., 2017. Changing odour landscapes: the effect of anthropogenic volatile pollutants on plant-pollinator olfactory communication. Funct. Ecol. 31, 56-64. https://doi.org/10.1111/1365-2435.12774.

Kantola, T., Tracy, J.L., Baum, K.A., Quinn, M.A., Coulson, R.N., 2019. Spatial risk assessment of eastern monarch butterfly road mortality during autumn migration within the southern corridor. Biol. Conserv. 231, 150-160. https://doi.org/10.1016/ j.biocon.2019.01.008.

Kasten, K., Stenoien, C., Caldwell, W., Oberhauser, K.S., 2016. Can roadside habitat lead monarchs on a route to recovery? J. Insect Conserv. 20, 1047-1057. https://doi.org/ 10.1007/s10841-016-9938-y.

Kaul, A.D., Wilsey, B.J., 2019. Monarch butterfly host plant (milkweed Asclepias spp.) abundance varies by habitat type across 98 prairies. Restor. Ecol. 1-8. https://doi. org/10.1111/rec.12993.

Keilsohn, W., Narango, D.L., Tallamy, D.W., 2018. Roadside habitat impacts insect traffic mortality. J. Insect Conserv. 22, 183-188. https://doi.org/10.1007/s10841-018 0051-2.

Klein, A.-M., Vaissiere, B.E., Cane, J.H., Steffan-Dewenter, I., Cunningham, S.A., Kremen, C., Tscharntke, T., 2007. Importance of pollinators in changing landscapes for world crops. Proc. R. Soc. B Biol. Sci. 274, 303-313. https://doi.org/10.1098/rspb.2006. 3721.

Knight, S.M., Norris, D.R., Derbyshire, R., Flockhart, D.T.T., 2019. Strategic mowing of roadside milkweeds increases monarch butterfly oviposition. Glob. Ecol. Conserv. 19, e00678. https://doi.org/10.1016/j.gecco.2019.e00678.

Leonard, R.J., Wat, K.K.Y., McArthur, C., Hochuli, D.F., 2018. Urbanisation and wing asymmetry in the western honey bee (Apis mellifera, Linnaeus 1758) at multiple scales. PeerJ 6, e5940. https://doi.org/10.7717/peerj.5940.

Leonard, R.J., Vergoz, V., Proschogo, N., McArthur, C., Hochuli, D.F., 2019. Petrol exhaust pollution impairs honey bee learning and memory. Oikos 128, 264-273. https://doi.org/10.1111/oik.05405.

Lövei, G., Macleod, A., Hickman, J., 1998. Dispersal and effects of barriers on the movement of the New Zealand hover fly Melanostoma fasciatum (Dipt., Syrphidae) on cultivated land. J. Appl. Entomol. 122, 115-120. https://doi.org/10.1111/j.14390418.1998.tb01471.x.

Lusebrink, I., Girling, R.D., Farthing, E., Newman, T.A., Jackson, C.W., Poppy, G.M., 2015. The effects of diesel exhaust pollution on floral volatiles and the consequences for honey bee olfaction. J. Chem. Ecol. 41, 904-912. https://doi.org/10.1007/ s10886-015-0624-4. 
Macgregor, C.J., Evans, D.M., Fox, R., Pocock, M.J.O., 2017. The dark side of street lighting: impacts on moths and evidence for the disruption of nocturnal pollen transport. Glob. Chang. Biol. 23, 697-707. https://doi.org/10.1111/gcb.13371.

Martin, A.E., Graham, S.L., Henry, M., Pervin, E., Fahrig, L., 2018. Flying insect abun dance declines with increasing road traffic. Insect Conserv. Divers. 11, 608-613. https://doi.org/10.1111/icad.12300.

Menzel, R., Tison, L., Fischer-Nakai, J., Cheeseman, J., Balbuena, M.S., Chen, X., Landgraf, T., Petrasch, J., Polster, J., Greggers, U., 2019. Guidance of navigating honeybees by learned elongated ground structures. Front. Behav. Neurosci. 12, 1-14. https://doi.org/10.3389/fnbeh.2018.00322.

Mitchell, T.S., Shephard, A.M., Kalinowski, C.R., Kobiela, M.E., Snell-Rood, E.C., 2019. Butterflies do not alter oviposition or larval foraging in response to anthropogenic increases in sodium. Anim. Behav. 154, 121-129. https://doi.org/10.1016/j. anbehav.2019.06.015.

Monarch Joint Venture, 2020. Roadside Habitat for Monarchs [WWW Document]. URL. https://monarchjointventure.org/roadsidehabitat.

Mora Alvarez, B.X., Carrera-Treviño, R., Hobson, K.A., 2019. Mortality of monarch butterflies (Danaus plexippus) at two highway crossing "hotspots" during Autumn migration in northeast Mexico. Front. Ecol. Evol. 7, 1-7. https://doi.org/10.3389/fevo. 2019.00273.

Munguira, M.L., Thomas, J.A., 1992. Use of road verges by butterfly and burnet populations, and the effect of roads on adult dispersal and mortality. J. Appl. Ecol. 29, 316-329. https://doi.org/10.2307/2404501.

Muñoz, P.T., Torres, F.P., Megías, A.G., 2015. Effects of roads on insects: a review. Biodivers. Conserv. 24, 659-682. https://doi.org/10.1007/s10531-014-0831-2.

Noordijk, J., Delille, K., Schaffers, A.P., Sýkora, K.V., 2009. Optimizing grassland management for flower-visiting insects in roadside verges. Biol. Conserv. 142 , 2097-2103. https://doi.org/10.1016/j.biocon.2009.04.009.

Öckinger, E., Smith, H.G., 2007. Semi-natural grasslands as population sources for pollinating insects in agricultural landscapes. J. Appl. Ecol. 44, 50-59. https://doi.org/ 10.1111/j.1365-2664.2006.01250.x.

Oleksa, A., Gawroński, R., Tofilski, A., 2013. Rural avenues as a refuge for feral honey bee population. J. Insect Conserv. 17, 465-472. https://doi.org/10.1007/s10841-0129528-6.

Ollerton, J., Winfree, R., Tarrant, S., 2011. How many flowering plants are pollinated by animals? Oikos 120, 321-326. https://doi.org/10.1111/j.1600-0706.2010.18644.x.

Orłowski, G., Karg, J., Kamiński, P., Baszyński, J., Szady-Grad, M., Ziomek, K., Klawe, J.J., 2019. Edge effect imprint on elemental traits of plant-invertebrate food web components of oilseed rape fields. Sci. Total Environ. 687, 1285-1294. https://doi. org/10.1016/j.scitotenv.2019.06.022.

Osgathorpe, L.M., Park, K., Goulson, D., 2012. The use of off-farm habitats by foraging bumblebees in agricultural landscapes: implications for conservation management. Apidologie 43, 113-127. https://doi.org/10.1007/s13592-011-0083-z.

Pawson, S., Bader, M.-F., 2014. LED lighting increases the ecological impact of light pollution irrespective of color temperature. Ecol. Appl. 24, 1561-1568. https://doi. org/10.1890/14-0468.1.

Phillips, B.B., Gaston, K.J., Bullock, J.M., Osborne, J.L., 2019. Road verges support pollinators in agricultural landscapes, but are diminished by heavy traffic and summer cutting. J. Appl. Ecol. 56, 2316-2327. https://doi.org/10.1111/1365-2664.13470.

Phillips, B.B., Bullock, J.M., Osborne, J.L., Gaston, K.J., 2020. Ecosystem service provision by road verges. J. Appl. Ecol. https://doi.org/10.1111/1365-2664.13556.

Pitman, G.M., Flockhart, D.T.T., Norris, D.R., 2018. Patterns and causes of oviposition in monarch butterflies: implications for milkweed restoration. Biol. Conserv. 217, 54-65. https://doi.org/10.1016/j.biocon.2017.10.019.

Plantlife, 2013. Flowers on the Edge, Press Release [WWW Document]. URL. http:// www.plantlife.org.uk.

Plantlife, 2020. Road Verge Campaign [WWW Document]. URL. http://plantlife.lovewildflowers.org.uk/roadvergecampaign.

Polic, D., Fiedler, K., Nell, C., Grill, A., 2014. Mobility of ringlet butterflies in high-elevation alpine grassland: effects of habitat barriers, resources and age. J. Insect Conserv. 18, 1153-1161. https://doi.org/10.1007/s10841-014-9726-5.

Potts, S.G., Imperatriz-Fonseca, V., Ngo, H.T., Aizen, M.A., Biesmeijer, J.C., Breeze, T.D., Dicks, L.V., Garibaldi, L.A., Hill, R., Settele, J., Vanbergen, A.J., 2016. Safeguarding pollinators and their values to human well-being. Nature 540, 220-229. https://doi. org/10.1038/nature20588.

R Core Team, 2019. R: A Language and Environmental for Statistical Computing. R Foundation for Statistical Computing, Vienna, Austria.

Rao, R.R.S.P., Girish, M.K.S., 2007. Road kills: assessing insect casualties using flagship taxon. Curr. Sci. 92, 830-837. https://doi.org/10.1016/S0921-5093(00)02014-1.

Reitmayer, C.M., Ryalls, J.M.W., Farthing, E., Jackson, C.W., Girling, R.D., Newman, T.A., 2019. Acute exposure to diesel exhaust induces central nervous system stress and altered learning and memory in honey bees. Sci. Rep. 9, 1-9. https://doi.org/10. 1038/s41598-019-41876-w.

Remon, J., Chevallier, E., Prunier, J.G., Baguette, M., Moulherat, S., 2018. Estimating the permeability of linear infrastructures using recapture data. Landsc. Ecol. 33, 1697-1710. https://doi.org/10.1007/s10980-018-0694-0.

Ries, L., Debinski, D.M., 2001. Butterfly responses to habitat edges in the highly fragmented prairies of Central Iowa. J. Anim. Ecol. 70, 840-852. https://doi.org/10. 1046/j.0021-8790.2001.00546.x.

Ries, L., Debinski, D.M., Wieland, M.L., 2001. Conservation value of roadside prairie restoration to butterfly communities. Conserv. Biol. 15, 401-411. https://doi.org/10. 1046/j.1523-1739.2001.015002401.x.

Riva, F., Acorn, J.H., Nielsen, S.E., 2018. Localized disturbances from oil sands developments increase butterfly diversity and abundance in Alberta's boreal forests. Biol. Conserv. 217, 173-180. https://doi.org/10.1016/j.biocon.2017.10.022.

Rohatgi, A., 2015. WebPlotDigitizer [WWW Document]. URL. https://automeris.io/ WebPlotDigitizer.

Saarinen, K., Valtonen, A., Jantunen, J., Saarnio, S., 2005. Butterflies and diurnal moths along road verges: does road type affect diversity and abundance? Biol. Conserv. 123, 403-412. https://doi.org/10.1016/j.biocon.2004.12.012.

Schaffers, A.P., Raemakers, I.P., Sýkora, K.V., 2012. Successful overwintering of arthropods in roadside verges. J. Insect Conserv. 16, 511-522. https://doi.org/10. 1007/s10841-011-9437-0.

Severns, 2008. Road crossing behavior of an endangered grassland butterfly Icaricia icarioides fenderi macy (Lycaenidae), between a subdivided population. J. Lepid. Soc. 62, 53-56.

Skórka, P., 2016. The detectability and persistence of road-killed butterflies: an experimental study. Biol. Conserv. 200, 36-43. https://doi.org/10.1016/j.biocon.2016.05. 026.

Skórka, P., Lenda, M., Moroń, D., Kalarus, K., Tryjanowski, P., 2013. Factors affecting road mortality and the suitability of road verges for butterflies. Biol. Conserv. 159, 148-157. https://doi.org/10.1016/j.biocon.2012.12.028.

Skórka, P., Lenda, M., Moroń, D., Martyka, R., Tryjanowski, P., Sutherland, W.J., 2015. Biodiversity collision blackspots in Poland: separation causality from stochasticity in roadkills of butterflies. Biol. Conserv. 187, 154-163. https://doi.org/10.1016/j. biocon.2015.04.017.

Skórka, P., Lenda, M., Moroń, D., 2018. Roads affect the spatial structure of butterfly communities in grassland patches. PeerJ 6, e5413. https://doi.org/10.7717/peerj. 5413.

Snell-Rood, E.C., Espeset, A., Boser, C.J., White, W.A., Smykalski, R., 2014. Anthropogenic changes in sodium affect neural and muscle development in butterflies. Proc. Natl. Acad. Sci. 111, 10221-10226. https://doi.org/10.1073/pnas. 1323607111.

Söderström, B., Hedblom, M., 2007. Comparing movement of four butterfly species in experimental grassland strips. J. Insect Conserv. 11, 333-342. https://doi.org/10. 1007/s10841-006-9046-5.

Somers-Yeates, R., Hodgson, D., Mcgregor, P.K., Spalding, A., Ffrench-Constant, R.H., 2013. Shedding light on moths: shorter wavelengths attract noctuids more than geometrids. Biol. Lett. 9. https://doi.org/10.1098/rsbl.2013.0376.

Strachecka, A., Borsuk, G., Paleolog, J., Olszewski, K., Chobotow, J., Skoczylas, D., 2012 Body-surface metalloprotease activity in Apis mellifera L. workers relative to environmental pollution. Med. Weter. 68, 406-410.

Tälle, M., Deák, B., Poschlod, P., Valkó, O., Westerberg, L., Milberg, P., 2018. Similar effects of different mowing frequencies on the conservation value of semi-natural grasslands in Europe. Biodivers. Conserv. 27, 2451-2475. https://doi.org/10.1007/ s10531-018-1562-6.

Tracy, J.L., Kantola, T., Baum, K.A., Coulson, R.N., 2019. Modeling fall migration pathways and spatially identifying potential migratory hazards for the eastern monarch butterfly. Landsc. Ecol. 34, 443-458. https://doi.org/10.1007/s10980-019-00776-0.

Urbini, A., Sparvoli, E., Turillazzi, S., 2006. Social paper wasps as bioindicators: a preliminary research with Polistes dominulus (Hymenoptera Vespidae) as a trace metal accumulator. Chemosphere 64, 697-703. https://doi.org/10.1016/j.chemosphere. 2005.11.009.

Valtonen, A., Saarinen, K., 2005. A highway intersection as an alternative habitat for a meadow butterfly: effect of mowing, habitat geometry and roads on the ringlet (Aphantopus hyperantus). Ann. Zool. Fennici 42, 545-556.

Valtonen, A., Jantunen, J., Saarinen, K., 2006a. Flora and lepidoptera fauna adversely affected by invasive Lupinus polyphyllus along road verges. Biol. Conserv. 133, 389-396. https://doi.org/10.1016/j.biocon.2006.06.015.

Valtonen, A., Saarinen, K., Jantunen, J., 2006b. Effect of different mowing regimes on butterflies and diurnal moths on road verges. Anim. Biodivers. Conserv. 29, 133-148.

van Grunsven, R.H.A., Donners, M., Boekee, K., Tichelaar, I., van Geffen, K.G., Groenendijk, D., Berendse, F., Veenendaal, E.M., 2014. Spectral composition of light sources and insect phototaxis, with an evaluation of existing spectral response models. J. Insect Conserv. 18, 225-231. https://doi.org/10.1007/s10841-014 9633-9.

Viechtbauer, W., 2010. Conducting meta-analyses in R with the metafor. J. Stat. Softw. 36, 1-48. https://doi.org/10.18637/jss.v036.i03.

Villemey, A., Peterman, W.E., Richard, M., Ouin, A., van Halder, I., Stevens, V.M., Baguette, M., Roche, P., Archaux, F., 2016. Butterfly dispersal in farmland: a replicated landscape genetics study on the meadow brown butterfly (Maniola jurtina). Landsc. Ecol. 31, 1629-1641. https://doi.org/10.1007/s10980-016-0348-Z.

Villemey, A., Jeusset, A., Vargac, M., Bertheau, Y., Coulon, A., Touroult, J., Vanpeene, S., Castagneyrol, B., Jactel, H., Witte, I., Deniaud, N., Flamerie De Lachapelle, F., Jaslier, E., Roy, V., Guinard, E., Le Mitouard, E., Rauel, V., Sordello, R., 2018. Can linear transportation infrastructure verges constitute a habitat and/or a corridor for insects in temperate landscapes? A systematic review. Environ. Evid. 7, 1-33. https://doi. org/10.1186/s13750-018-0117-3.

Wakefield, A., Stone, E.L., Jones, G., Harris, S., 2015. Light-emitting diode street lights reduce last-ditch evasive manoeuvres by moths to bat echolocation calls. R. Soc. Open Sci. 2. https://doi.org/10.1098/rsos.150291.

Wakefield, A., Broyles, M., Stone, E.L., Harris, S., Jones, G., 2018. Quantifying the attractiveness of broad-spectrum street lights to aerial nocturnal insects. J. Appl. Ecol. 55, 714-722. https://doi.org/10.1111/1365-2664.13004.

Wan, X., Wang, W., Liu, J., Tong, T., 2014. Estimating the sample mean and standard deviation from the sample size, median, range and/or interquartile range. BMC Med. 
Res. Methodol. 14, 1-13. https://doi.org/10.1186/1471-2288-14-135.

Wuellner, C.T., 1999. Nest site preference and success in a gregarious, ground-nesting bee Dieunomia triangulifera. Ecol. Entomol. 24, 471-479. https://doi.org/10.1046/j 1365-2311.1999.00215.x.

Wynhoff, I., van Gestel, R., van Swaay, C., van Langevelde, F., 2011. Not only the butterflies: managing ants on road verges to benefit Phengaris (Maculinea) butterflies. J. Insect Conserv. 15, 189-206. https://doi.org/10.1007/s10841-010-9337-8.

Xerces Society, 2020. Managing Roadsides and Rights-of-way for Pollinators [WWW Document]. URL, https://xerces.org/pollinator-conservation/roadsides.

Zarić, N.M., Ilijević, K., Stanisavljević, L., Gržetić, I., 2016. Metal concentrations around thermal power plants, rural and urban areas using honeybees (Apis mellifera L.) as bioindicators. Int. J. Environ. Sci. Technol. 13, 413-422. https://doi.org/10.1007 s13762-015-0895-x.
Zarić, N.M., Ilijević, K., Stanisavljević, L., Gržetić, I., 2018. Use of honeybees (Apis mellifera L.) as bioindicators of spatial variations and origin determination of metal pollution in Serbia. J. Serbian Chem. Soc. 83, 773-784. https://doi.org/10.2298/ JSC171110018Z

Zhou, X., Taylor, M.P., Davies, P.J., Prasad, S., 2018. Identifying sources of environmental contamination in European honey bees (Apis mellifera) using trace elements and lead isotopic compositions. Environ. Sci. Technol. 52, 991-1001. https://doi.org/10. 1021/acs.est.7b04084.

Zielin, S.B., Littlejohn, J., de Rivera, C.E., Smith, W.P., Jacobson, S.L., 2016. Ecological investigations to select mitigation options to reduce vehicle-caused mortality of a threatened butterfly. J. Insect Conserv. 20, 845-854. https://doi.org/10.1007/ s10841-016-9916-4. 